\title{
U.S. Savings Banks' Demutualization and Depositor Welfare
}

\author{
Mattia Girotti ${ }^{1}$ \& Richard Meade ${ }^{2}$
}

August 2017, WP \#639

\begin{abstract}
Originally, U.S. savings banks were owned by their depositors. In recent decades, many savings banks have "demutualized", by converting from customer to investor ownership. We examine the implications of such events for depositor welfare. We introduce a random coefficients logit model of bank account choice and estimate depositors' tastes for bank characteristics (including banks' ownership type). We then measure the effect on depositor welfare of a simulated demutualization of all customer-owned savings banks. We find that depositors' welfare would increase on average. In particular, if demutualized savings banks offered a deposit rate in line with existing demutualized banks, each depositor would gain $\$ 1.14$ annually, for a total of $\$ 22$ million for each state and year. ${ }^{3}$
\end{abstract}

Keywords: Banks, Deposits, Demand Estimation, Customer Ownership, Mutuals.

JEL classification: D12, G21, L21, P13.

\footnotetext{
${ }^{1}$ Banque de France; mattia.girotti@banque-france.fr

${ }^{2}$ Auckland University of Technology, and Cognitus Economic Insight; richard.meade@,cognitus.co.nz

3 The authors would like to thank Philippe Choné, Hans Degryse, Pierre Dubois, Jorge Florez, Laura Lasio, Daniel Herrera, Thierry Magnac, Fabiano Schivardi, and Angelo Zago, for their comments and suggestions.

Working Papers reflect the opinions of the authors and do not necessarily express the views of the Banque de France. This document is available on publications.banque-france.fr/en
} 


\section{NON-TECHNICAL SUMMARY}

Many banking systems around the world feature banks owned by their customers, as well as those owned by investors. In this paper, we study the effects on depositor welfare of the conversion from customer to investor ownership (i.e., the "demutualization") of U.S. savings banks. Our findings indicate that 1) depositors base their choice of bank deposit account on the bank ownership type, and 2) that they, on average, would benefit from a demutualization of customer-owned savings banks.

Historically, all U.S. savings banks were customer-owned. They were established in the nineteenth century as a means of providing banking services to households and small firms, which were unprofitable for commercial banks to serve. Indeed, customer ownership is associated with the joint maximization of profits and customer surplus, not just profits as in investor-owned banks. In recent decades, however, many customerowned savings banks demutualized. The following figure shows that between 1994 and 2005 from four to eight per cent of the existing customer-owned savings banks demutualized every year. Since customer ownership is associated with consumer surplus maximization, it is natural to consider the implications of demutualizations for customer welfare.

\section{Number of demutualizations and percentage to the total}

This figure plots the quarterly evolution of the number of conversions of U.S. savings banks from customer to investor ownership. The data are from the FDIC, Statistics on Depository Institutions.

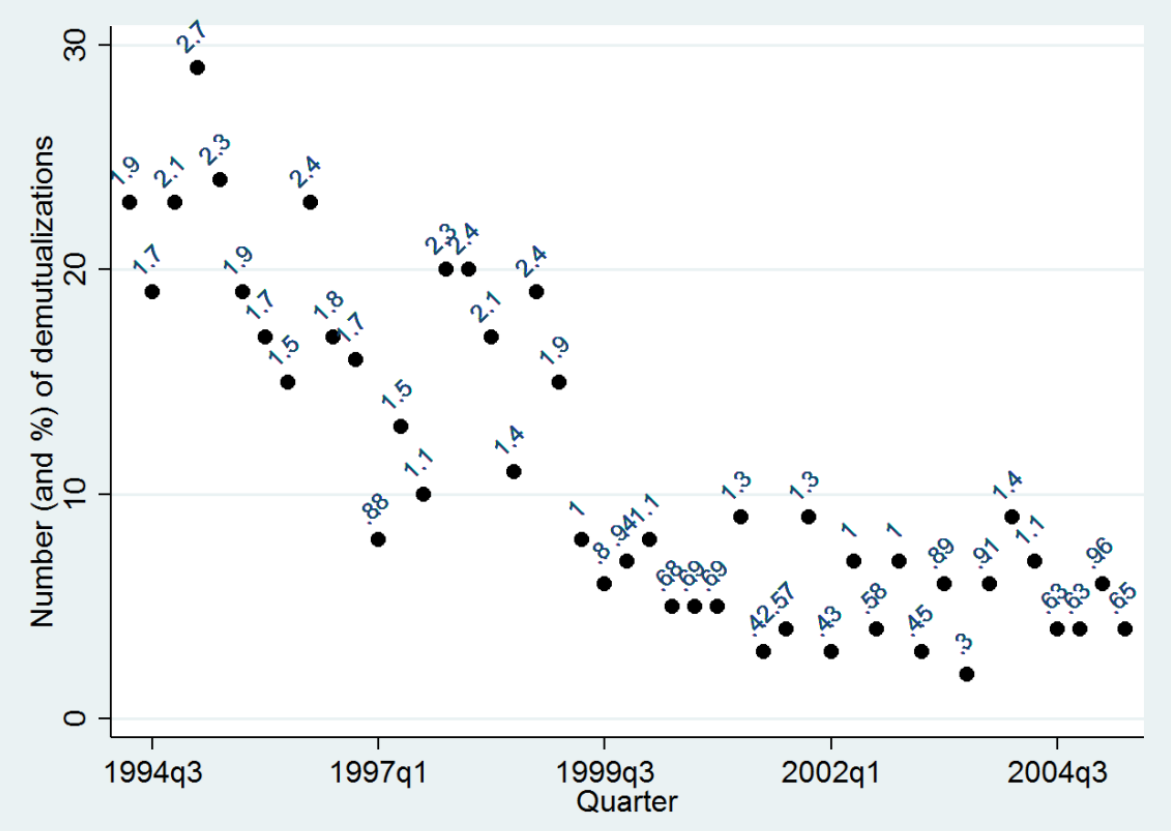

We first derive theoretically the implications of customer-ownership for bank performance. We obtain that customer-owned banks should offer a higher deposit rate than investor-owned banks. We then develop an empirical model of bank deposit account choice, in which each depositor derives utility from a bank account depending on the deposit rate offered and on other bank characteristics. Specifically, we allow for bank type - i.e. the attribute of "being a savings bank" (whether investor- or customer-owned), and more particularly "being customer-owned" - to feature in depositors' bank evaluations, as well as in depositors' sensitivity to the deposit rate offered. We estimate our empirical deposit supply model using state-level data for U.S. commercial and savings banks from 1994 to 2005. 
The estimation results indicate that depositors base their bank deposit choice on considerations beyond just deposit rate, and even their evaluation of deposit rate itself is influenced by other factors (here, bank ownership type). Most importantly, we find that customer-owned savings banks are perceived differently from investor-owned savings banks, and are preferred for a high level of the deposit rate. In light of our stylized theoretical investigation, we interpret these empirical findings as indicating that depositors prefer customer-owned savings banks to investor-owned savings banks only if they perceive that such banks are maximizing customer surplus in practice, and therefore paying sufficiently higher deposit rates.

The parameters that we recover from the estimation represent the estimates of depositor tastes' for each of the bank characteristics. We then use them to conduct the policy experiment in which all customer-owned savings banks are assumed to convert to investor ownership, and estimate the impact of this on depositor welfare. We obtain that every depositor would gain, on average, more than one dollar (\$1.14) per year if demutualized banks lost their "customer-ownership" attribute and offered a deposit rate in line with other investor-owned savings banks. The corresponding market-wide welfare effect of such simulated demutualization is estimated to be $\$ 22$ million per state-year.

Our conclusion is that depositors, on average, would benefit from a demutualization of customer-owned savings banks. As highlighted above, such banks should, all other things being equal, offer higher deposit rates than investor-owned savings banks. In practice, customer- and investor-owned savings banks pay similar deposit rates, and sometimes investor-owned savings offer higher rates. So, on the one hand customer-owned savings banks do not pay deposits "enough" to be perceived customer surplus maximizers. On the other hand, if demutualized savings banks paid the same as other investor-owned savings banks, they would offer higher rates than if they were still customer-owned. This is why a complete demutualization is expected to increase depositors' welfare.

\title{
Démutualisation des banques d'épargne des États- Unis et bien-être des déposants
}

\begin{abstract}
RÉSUMÉ
Historiquement, les caisses d'épargne des États-Unis ont appartenu à leurs déposants. Au cours des dernières décennies, des nombreuses caisses d'épargne ont été «démutualisées», c'est-à-dire qu'elles ne sont plus la propriété de leurs clientèles mais sont devenues la propriété d'investisseurs. Nous examinons les implications de ces événements pour le bien-être des déposants. Nous introduisons un modèle logit à coefficients aléatoires de choix de dépôt bancaire, et estimons les goûts des déposants pour les caractéristiques bancaires (y compris le type de propriété des banques). Nous mesurons ensuite l'effet sur le bien-être des déposants d'une démutualisation simulée de toutes les caisses d'épargne appartenant à leurs clientèles. Nous constatons qu'en moyenne, le bien-être des déposants augmenterait. En particulier, si les caisses d'épargne démutualisées offraient un taux de dépôt similaire aux banques démutualisées déjà existantes, chaque déposant gagnerait $1,14 \$$ par année, soit un total de 22 millions de dollars pour chaque état des États-Unis et chaque année.
\end{abstract}

Mots-clés : banques, dépôts, estimation de la demande, coopératives.

Les Documents de travail reflètent les idées personnelles de leurs auteurs et n'expriment pas nécessairement la position de la Banque de France. Ce document est disponible sur publications.banque-france.fr 


\section{Introduction}

Many banking systems around the world feature banks owned by their customers, as well as those owned by investors. Historically, all U.S. savings banks were customer-owned. They were established in the nineteenth century as a means of providing banking services to households and small firms, which were unprofitable for commercial banks to serve. ${ }^{1}$ Indeed, customer ownership is associated with the joint maximization of profits and customer surplus, not just profits as in investor-owned banks. Since the 1980s, however, many savings banks have "demutualized", by converting from customer ownership to investor ownership.

The question we raise in this paper is what is the effect on depositor welfare of such demutualizations. A priori, with demutualization, banks no longer maximize the combination of profits and customer surplus. This suggests such events could result in a welfare loss for depositors. We address this question by estimating a structural model of bank deposit account choice, and then measure the effect on depositor welfare of a simulated demutualization of all customer-owned savings banks.

To fix ideas, we first develop a stylized theoretical model predicting the impact of ownership type on bank performance. That model suggests that customer-owned banks should offer a higher deposit rate than investor-owned banks. We then develop a random coefficients logit model of bank deposit account choice, in which each depositor derives utility from a bank account depending on the deposit rate offered, and on other bank characteristics, allowing depositors to differ in their "taste" for these attributes. Importantly, we allow for bank type - i.e. the attribute of "being a savings bank" (whether investor- or customer-owned), and more particularly "being customer-owned" - to feature in depositors' bank evaluations, as well as in depositors' sensitivity to the deposit rate offered.

As in any estimation of a supply equation we need to deal with the simultaneity problem that makes the price - in our case, deposit rate - endogenous. Our approach is to instrument the deposit rate using a shifter of banks' deposit demand. This shifter is

\footnotetext{
${ }^{1}$ See, for example, Hansmann (1996), Fonteyne (2007), Ayadi et al. (2010).
} 
derived from regulatory changes implemented under the Riegle-Neal Act of 1994. This legislation relaxed branching restrictions that previously impeded commercial banks from branching out of their home state, and had the effect of increasing banking market competition and deposit demand (Rice and Strahan (2010)). Using state-level data for U.S. commercial and savings banks from 1994 to 2005, we then estimate our empirical deposit supply model using the approach of Berry et al. (2005), as refined by Nevo (2000, 2001) and Knittel and Metaxoglou (2014).

Our estimation indicates that depositors base their bank deposit choice on considerations beyond just deposit rate, and even their evaluation of deposit rate itself is influenced by other factors (here, bank ownership type). Indeed, having an account at a bank gives the depositor access to a range of services offered by that bank, such as loans or investment products. The range of such additional services appears limited in savings banks, which focus almost exclusively on residential mortgage lending. Consistently, we find that depositors respond less favourably to a deposit rate if offered by a savings bank, and that "being a savings bank" leads to a lower utility on average. However, we find that customer-owned savings banks are perceived differently from investor-owned savings banks, and are preferred for a high level of the deposit rate. According to our stylized theoretical model, customer-owned banks should offer higher deposit rates than investorowned competitors. Our empirical findings may then be interpreted as indicating that depositors prefer customer-owned savings to investor-owned savings banks only if they perceive that customer-owned banks are maximizing customer surplus in practice, and therefore paying sufficiently higher deposit rates.

Having obtained depositor tastes' estimates, we conduct the policy experiment in which all customer-owned savings banks are assumed to demutualize, and estimate the impact of this on depositor welfare. Specifically, we consider two scenarios: one, in which demutualized banks change only their attribute of "being customer-owned" and offer their pre-demutualization deposit rates; and another in which they offer a deposit rate in line with other investor-owned savings banks. We estimate that every depositor would gain, on average, 36 cents if demutualized banks lost their "customer-ownership" attribute and 
maintained their pre-demutualization deposit rates. This amount increases to more than one dollar $(\$ 1.14)$ per year if demutualized banks offered a deposit rate in line with other investor-owned savings banks. We compute the corresponding market-wide welfare effect of such simulated mass demutualization. We obtain that aggregate depositor welfare would increase by, respectively, $\$ 6$ million and $\$ 22$ million per state-year.

Our conclusion is that depositors, on average, would benefit from a demutualization of customer-owned savings banks. As highlighted above, such banks should, all other things being equal, offer higher deposit rates than investor-owned savings banks. Hence depositors value the attribute of "being customer-owned" only if these banks are perceived to pursue the objective of customer surplus maximization, and pay deposits more. In practice, customer- and investor-owned savings banks pay similar deposit rates, and sometimes investor-owned savings offer higher rates. So, on the one hand customer-owned savings banks do not pay deposits "enough" to be perceived customer surplus maximizers. On the other hand, if demutualized savings banks paid the same as other investor-owned savings banks, they would offer higher rates than if they were still customer-owned. This is why a complete demutualization is expected to increase depositors' welfare.

The existing literature on U.S. savings banks' demutualization has focused mainly on these events from the perspective of the banks involved. Hadaway and Hadaway (1981), Masulis (1987), and Chaddad and Cook (2004) suggest that the main reason savings institutions decide to demutualize is to improve access to capital. Additionally, Kroszner and Strahan (1996) find that regulation incentivized savings banks to convert to stock form in the 1980s. Given better access to capital, newly demutualized savings banks can better pursue growth opportunities, and are found to enjoy improved performance (Cole and Mehran (1998)). However, such higher performance comes from higher risk taking (Cordell, Mac Donald, and Wohar (1993), and Esty (1997)), so potentially impairing the positive effect at the aggregate level. As argued by Chaddad and Cook (2004), however, "the literature is silent about distributional effects related to demutualizations, particularly the effects on depositors". Ours is the first paper, to our knowledge, to address depositor welfare considerations of demutualizations. 
This paper also adds to the growing literature that applies discrete choice models to banking. The studies closest to ours are Dick (2002, 2008) and Ho and Ishii (2011), which measure the effect on depositors' welfare of the U.S. deregulation changes in the 1990s. While Dick $(2002,2008)$ focuses on commercial banks only, Ho and Ishii (2011) also include savings banks and credit unions in their analysis, but do not distiguish between investor-owned and customer-owned savings banks. Also considering the U.S., Adams et al. (2007) estimate a generalized extreme value model of deposit supply choice in both commercial and savings banks. They assess the degree of market segmentation for these two institutional subgroups, and find that there is limited substitution across commercial and savings institutions. Other applications of discrete choice models to non-U.S. banking environments include Molnar et al. (2006), Nakane et al. (2006), Perez Montes (2014), and Crawford et al. (2017). Overall, none of these analyses measures consumers' taste for bank ownership type, hence ours is the first to do so.

This paper is organized as follows. Section 2 describes the types of banking institutions operating in the U.S.. Section 3 sets out the deposit supply specification, and Section 4 presents the estimation results. Section 5 describes our policy experiment, and the related results. Finally, Section 6 concludes.

\section{Types of Banking Institutions in the U.S. ${ }^{2}$}

The U.S. banking system is characterized by a variety of bank types. As illustrated in Figure 1, U.S. banks can be distinguished by whether they are commercial banks or thrifts. Thrifts can be further characterized by their type of charter (i.e. the legal authority to operate a bank), being either savings banks, savings and loans (S\&Ls), or credit unions, and also by whether they are owned by their customers, or investors.

\footnotetext{
${ }^{2}$ This section is based on chapters 4 and 6 of Federal Deposit Insurance Corporation (1997), chapter 1 of Williams (2006), Wilcox (2006), Barth et al. (2009), and web chapter 25 of Mishkin and Eakins (2012). Regulatory information was also obtained from legal and accounting publications on the website of the U.S. Department of the Treasury's Office of the Comptroller of the Currency, www.occ.gov.
} 


\subsection{Historical Origins and Recent Dynamics}

Commercial banks in the U.S. first emerged in 1781. They arose to serve the banking needs of commercial customers, rather than offering depository or mortgage lending services to smaller customers such as households. Mutual savings banks were created to fill this gap, with the Philadelphia Saving Fund Society, and the Boston-based Provident Institution for Savings, commencing operations in 1816. Such banks were intended to encourage savings among the working and lower classes. They became prominent in the Mid-Atlantic and industrial North-East states, which had a large number of wageearners. Savings and loans emerged soon after mutual savings banks, with the Oxford Provident Building Association commencing operations in 1831. Whereas mutual savings banks were originally conceived with the intent of encouraging savings, and only later offered mortgage lending, S\&Ls were specifically created to facilitate home ownership by individuals. By pooling members' savings, S\&Ls could satisfy the mortgage needs of the growing working class. ${ }^{3}$ In the rest of the paper, we refer to savings banks and S\&Ls generically as "savings banks".

Commercial banks and savings banks originally differed in terms of how they were regulated, and ownership structure. Unlike commercial banks, savings banks have faced lending limits since their inception. Regulation currently requires that commercial and small business loans cannot make up more than $20 \%$ of a savings bank's assets, and consumer loans and corporate debt cannot make up more than $35 \%$. Residential real estate loans can be up to $400 \%$ of capital. As a result, savings banks focus almost exclusively on mortgage lending. Regulation does not differ with respect to capital requirements, and since 1951 with respect to income taxes. ${ }^{4}$

In terms of ownership structure, since their inception commercial banks have been exclusively investor-owned, returning profits to stock-holders. Conversely, savings banks were all initially customer-owned, with the depositors being the owners. ${ }^{5}$ Following

\footnotetext{
${ }^{3}$ Credit Unions emerged much later, in 1909. They were created to meet demand for loans initially not met by either commercial banks, mutual savings banks, or S\&Ls. Nowadays these include loans for automobiles and home improvement. Following the original German model, credit unions enabled a group with little capital but a common bond to raise a loan which they were collectively liable to repay.

${ }^{4}$ Unlike Credit Unions, which continue to be tax-exempt.

${ }^{5}$ Mutual savings banks originally differed from S\&Ls in terms of corporate governance. While members
} 
the passage of enabling legislation in 1948, savings banks were allowed to "demutualize", meaning they could then convert from customer-ownership to investor-ownership. Customer-owned savings banks cannot issue new shares to investors, and have historically relied on retained earnings as their only source of capital. ${ }^{6}$ Demutualizations have thus enabled access to new capital, facilitating bank mergers and takeovers.

Historically, commercial banks have dominated savings banks in terms of both number and total assets. ${ }^{7}$ As Figure 2 shows, between 1994 and 2005, which is our period of analysis, commercial banks are more numerous than both types of savings banks. However, the number of banks markedly reduced over time for all bank types. Most importantly, many savings banks have converted to investor ownership. Figure 3 shows that in the period considered, the number of demutualizations is large. For example, between 1994 and 1999, $8 \%$ of existing customer-owned savings banks demutualized every year. Motivated by this dynamics, the question we raise in this paper is whether depositors benefit from such demutualizations.

\subsection{The Implications of Customer-Ownership}

The original objective of savings banks was to provide banking services to customers who would not have been served by commercial banks (Hansmann (1996), Fonteyne (2007), Ayadi et al. (2010)). Customer-ownership allowed savings banks to fulfil this objective, since customer-owned banks maximize not just profits, but the sum of profits and customer welfare. Customer-owned banks are therefore able to serve customers that would otherwise be left unserved by investor-owned banks.

To see more clearly how the ownership structure alters banks' behavior, we present in the Appendix a stylized model of banking under investor- and customer-ownership. We

of S\&Ls enjoyed voting rights over bank governors, "members" in mutual savings banks did not. In fact, following an original Scottish model, governors of mutual savings banks were often philanthropists and acted in a form of trustee capacity on behalf of the members.

${ }^{6}$ Bank reforms in the 1980s eased this constraint, by allowing the creation of bank holding companies. Bank holding companies facilitate access to external capital while ensuring continued majority depositor ownership.

${ }^{7}$ See Table 1 of Barth et al. (2009) for long-term historical figures for each bank type. 
consider an economy populated by two types of banks: investor-owned and customerowned. Both types of bank have zero capital, and lend every dollar they raise in deposits. They face a deposit supply that is upward sloping in the deposit rate, and a loan demand that is downward sloping in the loan rate. The key difference between bank types is that customer-owned banks maximize the surplus of both loan takers and deposit providers together with their profits, while investor-owned banks maximize only their profits. Banks engage in Bertrand-Nash competition in deposit rate, so each sets its deposit rate taking the others' moves as given.

This stylized model predicts that at equilibrium, customer-owned banks offer a greater deposit rate, charge a lower loan rate, and serve more customers than investor-owned banks. In this sense customer-ownership means customer-owned savings banks serve a greater portion of potential consumers. They achieve this by offering higher deposit rates and lower loan rates than investor-owned banks.

Ownership type is a characteristic that is immediately observable by customers. Given such visibility, and the effects that it has on the bank's activity, customers may take the ownership type as an indicator of the bank's objectives. Then, if customers choose where to open a bank account depending on the bank's objectives, their choice may ultimately be a function of the bank's ownership type. For instance, customer-owned banks may be preferred by customers who place a large emphasis on the objective of customer-welfare maximization. In the following Section, we develop a model of bank account choice that allows us to understand whether depositors value the fact that a bank is customer-owned or not. This will help us understanding what would happen to depositor welfare if all existing customer-owned savings banks demutualized.

\section{Empirical Model}

\subsection{Specification}

We develop an empirical model of bank deposit account choice, and estimate the extent to which depositors' choices depend on the deposit rate, on other bank characteristics (e.g. 
size of the branch network), and on bank type (i.e. commercial versus savings, investorowned versus customer-owned). Our methodology specifically allows for heterogenous "taste parameters" for bank characteristics across depositors. Traditional references for the methodology are Berry (1994), Berry et al. (1995) (hereafter BLP), and Nevo (2000, 2001).

We assume that depositor $i$ has chosen a dollar quantity to deposit $\left(I_{i}\right)$, but remains to choose in which bank $j$ to deposit it. ${ }^{8}$ Each bank $j$ is assumed to offer only one type of deposit. ${ }^{9}$ Depositor $i$ has exogenous income $y_{i}$ and can choose among $J$ alternatives. We assume that, conditional on choosing to make a deposit at bank $j$ in market $t$, the depositor derives indirect utility $u_{i j t}$ :

$u_{i j t}=\alpha_{i}\left(y_{i}+r_{j t}^{D} I_{i}\right)+\alpha_{i}^{S a v}\left(r_{j t}^{D} I_{i} \times S a v_{j t}\right)+\alpha_{i}^{\text {CustOwn }}\left(r_{j t}^{D} I_{i} \times C u s t O w n_{j t}\right)+x_{j t} \beta_{i}+\xi_{j t}+\varepsilon_{i j t}$

where $r_{j t}^{D}$ denotes the deposit rate offered by bank $j, S a v_{j t}$ denotes whether $j$ is a savings bank (irrespective of its ownership type), and CustOwn $n_{j t}$ denotes whether $j$ is customerowned. $x_{j t}$ is a vector of bank characteristics, other than the deposit rate, which are observed by the econometrician (including $\operatorname{Sav}_{j t}$, CustOwn $n_{j t}$, and time and geographic market fixed effects). Conversely, $\xi_{j t}$ represents bank characteristics unobserved by the econometrician. Finally, $\varepsilon_{i j t}$ is an iid Type 1 Extreme Value error term that captures consumer heterogeneity not explained by the customer-specific taste parameters $\alpha_{i}$ and $\beta_{i}$. Note that $\alpha_{i}$ is the marginal utility of income, which is assumed constant across the choice situations and the deposit rates being considered.

It is not uncommon in discrete choice models to include interaction terms between price (in our case $r_{j t}^{D}$ ) and product attributes (i.e. the ownership dummies $S a v_{j t}$ and CustOwn $\left.n_{j t}\right)$ in the utility specification. Comparable price interactions were included

\footnotetext{
${ }^{8}$ Conventionally, models such as ours are applied to estimate a product or service's demand. It could be said that a bank depositor demands deposit services from a bank. However, in what follows we more naturally characterize the depositors' choice regarding the bank where they make their deposit as one of deposit supply. This distinguishes deposit supply from bank customers' loan decision, which are more naturally treated as loan demand.

${ }^{9}$ This simplifying assumption is required because the data we use to estimate the model do not report the number of demand, savings or time deposit accounts a bank has in a market. Moreover, the data do not include the interest rates paid on each of these account types.
} 
in Nevo and Hatzitaskos (2006) in relation to food product choices, and in Moral and Jaumandreu (2007) in relation to automobile choices. Similarly, it is common to include price-brand interactions in marketing studies. The reason is that, for example, a given price might have a greater impact on consumer preferences for an "economy brand" than it would for a "luxury brand", since consumers expect to pay a higher price for luxury items (Raghavarao et al. (2010)). Such interactions are found to be important influencers of consumer product evaluations (Dodds et al. (1991)), and their omission is potentially important (Johnson and Olberts (1996)). We motivate our inclusion of the ownership dummy interactions on the basis that depositors expect customer-owned banks to offer higher deposit rates than comparable investor-owned banks (see the Subsection 2.2 and the theoretical model in the Appendix). As a consequence, depositors will view a given deposit rate less favourably if it is offered by a customer-owned savings bank than if it were offered by an investor-owned savings bank, all other things being equal. We also include an interaction between $r_{j t}^{D}$ and $S a v_{j t}$ to control for other features common to both investor- and customer-owned savings banks but not shared with commercial banks, so that our empirical specification can isolate the influence of customer-ownership on depositor preference for $r_{j t}^{D}$.

Since we do not observe individual deposits in our data, we normalize each depositor's deposit size to one, and correspondingly normalize depositor income by dividing it by deposit size. We further assume that such normalized income, denoted $\tilde{y}$, is constant across depositors, which is equivalent to assuming that depositors hold the same fixed ratio of income as deposits. Normalizing income does not modify the substance of the problem, since income $y_{i}$ enters linearly across any given depositor's choice alternatives. We can then re-write (1) as:

$$
u_{i j t}=\alpha_{i}\left(\tilde{y}+r_{j t}^{D}\right)+\alpha_{i}^{S a v}\left(r_{j t}^{D} \times \operatorname{Sav}_{j t}\right)+\alpha_{i}^{C u s t O w n}\left(r_{j t}^{D} \times C u s t O w n_{j t}\right)+x_{j t} \beta_{i}+\xi_{j t}+\varepsilon_{i j t}
$$

In addition to choosing at which bank $j$ to make a deposit (i.e. choosing an "inside good"), we allow for depositor $i$ to choose an alternative such as a credit union or a mutual fund (i.e. to choose an "outside good"). Thus, changing deposit rates will not 
only affect depositors' bank choices, but also whether they accept any bank at all. Since only relative utilities affect consumers' discrete choices, we are unable to identify taste coefficients for one good, so as usual we normalize the utility of the outside good to zero (i.e. $\left.u_{i 0 t} \equiv 0\right)$.

Our specification allows for heterogeneity in depositor tastes. ${ }^{10}$ This is achieved by introducing interactions between bank characteristics and depositor $i$ specific random variables. The introduction of customer-specific heterogeneity in the taste parameters $\beta_{i}$ and $\alpha_{i}$ was a key innovation in BLP. We follow their approach and decompose these parameters as:

$$
\left[\begin{array}{l}
\alpha_{i} \\
\beta_{i}
\end{array}\right]=\left[\begin{array}{l}
\alpha \\
\beta
\end{array}\right]+\Sigma v_{i} \quad v_{i} \sim P_{v}^{*}(v)
$$

with $v_{i}$ being a $(K+3) \times 1$ vector of random variables, distributed as $N\left(0, I_{K+3}\right)$ with $K$ being the number of observed non-price bank characteristics, and $\Sigma$ being a vector of scale parameters. ${ }^{11}$

Using (3), we can re-express (2) as:

$$
\begin{aligned}
u_{i j t} & =\underbrace{\alpha\left(\tilde{y}+r_{j t}^{D}\right)+\alpha^{S a v}\left(r_{j t}^{D} \times \operatorname{Sav}_{j t}\right)+\alpha^{C u s t O w n}\left(r_{j t}^{D} \times C u s t O w n_{j t}\right)+x_{j t} \beta+\xi_{j t}}_{\delta_{j t}\left(x_{j t}, r_{j t}^{D}, \xi_{j t} ; \theta\right)} \\
& +\underbrace{\left[r_{j t}^{D}, r_{j t}^{D} \times \operatorname{Sav}_{j t}, r_{j t}^{D} \times C u s t O w n_{j t}, x_{j t}\right]^{\prime} \Sigma v_{i}}_{\mu_{i j t}\left(x_{j t}, r_{j t}^{D}, v_{i} ; \Sigma\right)}+\varepsilon_{i j t}
\end{aligned}
$$

where $\alpha, \alpha^{\text {Sav }}, \alpha^{\text {CustOwn }}$ and $\beta$ represent mean taste parameters common to all depositors. This classifies the parameters depending on whether they enter linearly $(\theta \equiv$ $\left.\left(\alpha, \alpha^{\text {Sav }}, \alpha^{\text {CustOwn }}, \beta\right)\right)$ or non-linearly $(\Sigma)$ in the objective function used for estimation purposes. Here $\delta_{j t}$ represents the mean utility enjoyed by all depositors in bank $j$ and market $t$, depending on just $\theta$. Conversely, $\mu_{i j t}+\varepsilon_{i j t}$ represent depositor-specific zero-mean deviations from $\delta_{j t}$ due to making a deposit at bank $j$ in market $t$, with $\mu_{i j t}$ depending

\footnotetext{
${ }^{10}$ As highlighted in the literature, this allows for more reasonable substitution patterns (i.e. cross elasticities) between products than those obtainable with a multinomial logit specification. In a multinomial logit specification depositor tastes are homogeneous, so $\alpha_{i}=\alpha$ and $\beta_{i}=\beta$ for all depositors $i$. As discussed in Berry (1994), one important limitation of that specification is that price elasticities depend just on prices and market shares, leading to implausible substitution patterns.

${ }^{11}$ Note that we have $K+3$ elements in $v_{i}$ because we include the deposit rate interacted with two dummy variables as additional price-related characteristics.
} 
on $\Sigma$ and capturing the model's random coefficients.

We complete the specification by defining the set of depositors that choose bank $j$ in market $t$. Specifically, it comprises all depositors for whom making a deposit at bank $j$ provides greater utility than making that deposit at some other bank (or choosing the outside good) in market $t$, i.e.:

$$
A_{j t}=\left\{\left(v_{i}, \varepsilon_{i 0 t}, \ldots, \varepsilon_{i J t}\right) \mid u_{i j t} \geq u_{i l t}, \forall l \neq j\right\}
$$

With this definition of $A_{j t}$, the market share of bank (i.e. deposit product) $j$ in market $t$ is:

$$
s_{j t}=\int_{A_{j t}} \mathrm{~d} P^{*}(v, \varepsilon)=\int_{A_{j t}} \mathrm{~d} P_{v}^{*}(v) \mathrm{d} P_{\varepsilon}^{*}(\varepsilon)
$$

under the assumption that $v$ and $\varepsilon$ are independently distributed. So if the total size of market $t$ is $M_{t}$, then bank $j$ 's deposit supply in market $t$ is:

$$
q_{j t}^{D}=M_{t} s_{j t}
$$

while depositors' supply to the outside good in that market is $q_{0 t}=M_{t}\left(1-\sum_{j=1}^{J_{t}} s_{j t}\right)$.

\subsection{Data}

We obtain data on U.S. commercial and savings banks from the Federal Deposit Insurance Corporation (FDIC), which is the U.S. agency responsible for providing deposit insurance to account holders. A limitation of our data is that they do not contain information on credit unions. As a consequence, bank accounts at credit unions are included in the "outside good". The two datasets employed in our study are the Statistics on Depository Institutions (SDI), and the Summary of Deposits (SOD). The SDI records quarterly information on the institutional characteristics, balance sheet and income statement of each FDIC-insured institution. By contrast, the SOD provides, for each FDIC-insured institution, information on each branch location, and the amount of deposits there raised. 


\subsubsection{Geographic Market Definition}

The relevant geographic market for deposits is taken to be the state, for two reasons. First, selecting a finer geographical market would increase enormously the computational burden when implementing the random coefficients logit estimation. Second, we do not observe branch-specific interest rates, so such analysis would lack a fundamental component.

To see this better, it should be stressed that while the SOD allows us to precisely determine where each bank obtains its deposits, it does not record branch-specific interest payments, and hence we are unable to establish whether a given bank pays different interest rates across different branches. The deposit rates are derived from the SDI, which reports interest payments on a branch-consolidated basis. The interest rate we obtain is therefore bank-year specific. Also, these constraints imply that even if we used a finer geographical market definition, we would still have to use bank-year rates.

Taking the state as the relevant geographical market differs from earlier studies such as Dick $(2002,2008)$. In her analysis, Dick uses Metropolitan Statistical Areas for urban markets and counties for rural ones. This conforms with evidence that the market for financial services is local (Amel and Starr-McCluer (2002) and Kiser (2002)). However, Dick shares our limitations and is unable to define bank-market specific interest rates and product characteristics. It is therefore not clear whether the benefits in setting smaller geographical markets remain when no variation can be captured in the interest rates and product characteristics. In support of our approach, the assumption behind the selection of the state as the relevant geographic market is that deposit interest rates are set uniformly across branches by bank headquarters. This conforms with the evidence presented by Radecki (1998), who finds that banks typically set uniform rates at the state level. 


\subsubsection{Market Size and Outside Good}

Depositors select their bank as a discrete choice, but supply deposits as a continuous variable. Because our interest is in understanding the choice of bank, rather than the choice of quantity deposited, we obtain the number of accounts a bank serves in a given market. The SOD records for each bank branch the quantity of deposits obtained but not the number of accounts served. That information is available only on a branchconsolidated basis throught the SDI. This is problematic when a bank operates in more than one state in a given year. In that case, we do not observe from which state the accounts are obtained. We must therefore assign the total number of accounts served to each of the states in which the bank operates. We do so in proportion to the number of branches that the bank has in a given market. For example, if a bank has three branches, two in state A and one in state B, we assign two thirds of the bank's accounts to state A, and the rest to state $\mathrm{B} .{ }^{12}$ Information on branch location is available through the SOD as of every June 30. Despite the SDI providing quarterly figures, we are therefore constrained to using annual observations.

Once having recovered the number of accounts every bank has in each market, we need to proxy the market size. We first investigate which economic agents are typical depositors. Based on data from the U.S. Federal Reserve's Flow of Funds, we find that in 1994 $51 \%$ of checkable deposits was held by households, and $25 \%$ by non-financial businesses. In the same year, almost $100 \%$ of savings and time deposits was held by households. By contrast, in 2005, one third of outstanding checkable deposits and currency was held by households, and another third by non-financial businesses. Yet, $75 \%$ of total savings and time deposits was held by households. These figures suggest that households and firms are, in volume terms, the principal suppliers of all forms of deposits. Knowing how many households and firms reside in a market is thus essential for proxying the size of the market.

The total population of any given state and year is retrievable from the Bureau of Economic Analysis. Additionally, as argued by Adams et al. (2007), the number of

\footnotetext{
${ }^{12}$ This is very similar to the strategy adopted by Adams et al. (2007). In their case, however, they assign a bank's accounts proportionally to the dollar quantity of deposits obtained in each market.
} 
businesses in a market is very correlated to the market population. This means that the number of people in a market is already a sufficient statistic to proxy for the size of the market. We need, however, to scale the population size to account for the total bank account choices. We measure how many bank accounts a typical household maintains exploiting data from the Survey of Consumer Finances. We find that in both 1995 and 2004, the median number of accounts per household was 2, and the mean was 3 . When this figure is adjusted for the number of people that compose the household, it appears that the median number of accounts per person was 1, and the mean was 1.5. If, on top of those, we consider the deposit accounts held by businesses, it is likely that for every person the number of deposit accounts held is three. So, to proxy for the size of the market we scale population by a factor of three. This scaling factor, and the overall methodology, are in accordance with Adams et al. (2007). ${ }^{13}$

We compute market shares by dividing the number of bank accounts a bank serves in a given market by the size of that market. We observe, however, that the number of banks is very heterogeneous across markets, and sometimes very large (up to more than 1,000). A very large number of banks in the same market is problematic because it leads to a considerable computational burden when implementing the random coefficients logit model. To reduce this burden, we eliminate from the sample the banks with smaller market shares and that have a cumulative share of $10 \%$ or less in any given market. Having done this, the market share of the "outside good" is obtained as one minus the sum of the market shares of the "inside goods", i.e. the bank deposit accounts of those banks that we retain.

\footnotetext{
${ }^{13}$ Using this methodology, we find that in Delaware, New Hampshire, South Dakota, and Utah, the observed number of accounts exceeds the computed market size. This same problem is also experienced by Dick (2002, 2008), and Adams et al. (2007). One reason for Delaware having relatively large number of bank accounts may be that it is a an important commercial center and therefore hosts a lot of nonresident deposits. However, we have no explanation for the relatively high number of accounts in New Hampshire, South Dakota, and Utah. In any case, since the number of these markets is negligible compared to the rest, we omit them from our analysis.
} 


\subsubsection{Deposit Rate and Other Observed Bank Characteristics}

We construct bank-specific deposit rates and other explanatory variables based on the SDI. The proxying of the deposit rate $r_{j t}^{D}$ exploits the quarterly structure of the SDI. We first obtain quarterly interest rates by dividing domestic deposit interest payments realized during a quarter by the amount of domestic deposits outstanding at the end of the previous quarter. Then, we obtain the yearly interest rate, promised at a given point in time, compounding the gross quarterly interest rates realized in the subsequent four quarters and subtracting one. So, for example, the deposit rate promised by a bank in June 30, 1994, is taken to be the product of the gross quarterly interest rates realized during the third and fourth quarters of 1994, and the first and second quarters of 1995, minus one.

We then isolate bank type. The dummy $\operatorname{Sav}_{j t}$ equals one when the bank's charter is of a savings institution, while CustOwn $n_{j t}$ equals one when the bank is customer-owned. Note that only savings banks can be customer-owned. Thus, when CustOwn $n_{j t}$ is equal to one, so has to be $S a v_{j t}$.

For bank characteristics, we control for branch staffing, for the scope of the branch network, and for the strength of the customer relationships the bank may have built. All these characteristics are expected to have a positive effect on depositors' choice of bank. $x_{j t}$ thus includes the log of the number of employees per branch (Emplper branch $\left.{ }_{j t}\right)$, the log of the number of branches (Number of branches ${ }_{j t}$ ), the log of the branch density (Branch density ${ }_{j t}$ ), and a dummy variable capturing whether the bank's headquarters are located out of the state being considered (Out of Statebank $k_{j t}$ ) as a proxy for the bank's strength of customer relationship. ${ }^{14}$

In Table 1, we report summary statistics for market shares, deposit rates and bank characteristics at the bank-market level. We differentiate by bank type, and also report the starting and ending years in our sample separately. We see that our sample comprises 50,332 bank-year observations. Of these, 5,146 are for investor-owned savings, 3,063 ob-

\footnotetext{
${ }^{14}$ To be precise, Empl per branch $j t$ is obtained by first dividing the total number of employees by the total number of branches and taking the log, while Branch density ${ }_{j t}$ is computed dividing the number of branches a bank has in a state by the land area of that state in square miles and then taking the log. Data on states' land area come from the 2000 U.S. Census.
} 
servations are for customer-owned savings, and the rest are for commercials. We observe that investor-owned savings banks tend to have larger market shares than commercial banks and customer-owned savings banks. We also note that market shares increase over time for all ownership types. This indicates that the industry experienced a process of consolidation, as already remarked in Figure 2. As for deposit rates, their inter-temporal comparison is meaningless since they tend to be influenced by the outstanding monetary policy stance. However, cross-sectional differences reveal that savings banks, both customer- and investor-owned, pay in general higher deposit rates. In terms of branch staffing we do not observe marked differences both cross-sectionally and inter-temporally. Conversely, on average investor-owned savings banks are found to have more extensive branch networks than both commercial and customer-owned savings banks. It should be noted, however, that customer-owned savings have more dense branch networks than commercials. Still, in the three cases, the size of the branching network has increased over time. Finally, the presence of commercial out-of-state banks was modest in 1994, but increased dramatically by 2005 . The increase is shared by both customer- and investorowned savings banks. In our sample, investor-owned savings banks are the most present out of their home state, while customer-owned savings banks operate mainly in the state in which they are headquartered.

\subsection{Estimation and Instruments}

To estimate the random coefficients deposit supply model we exploit the technique originally proposed by BLP. The interested reader can find the details in the Appendix. Here, we only recall that as in any demand or supply estimation the price (in this case, the deposit rate) is correlated with the unobservable term (in this case, the unobservable characteristics $\left.\xi_{j t}\right)$. To see this better, suppose that a bank is geographically "well-located". This characteristic is unobservable to the econometrician. However, because of this characteristic, the bank is able to pay its depositors a lower deposit rate than its competitors. The observed deposit rate is then correlated with the unobservable component, and ne- 
glecting this correlation would result in biased estimates.

To resolve this endogeneity problem it is necessary to introduce suitable instruments for the deposit rate and its interactions. When estimating a supply equation, it is customary to use demand shifters as instruments for price, which is the approach we adopt here. Since our interest is in estimating deposit supply, we use bank demand shifters as instruments for the deposit rates. We derive these shifters from the staggered relaxation of commercial bank branching restrictions. This had the effect of promoting entry of out-of-state commercial banks and therefore increased the demand for deposits.

Until at least the 1980s, regulation on commercial banks' geographic expansion was strict and directed at both intra-state and inter-state banking and branching operations (Johnson and Rice (2008), and Kane (1996)). ${ }^{15}$ The situation changed with the RiegleNeal Interstate Banking and Branching Efficiency Act of 1994. First, the Act removed the last vestiges of state restrictions on inter-state bank acquisitions left from the deregulation of the 1980s. Second, the Act permitted the consolidation of existing out-of-state subsidiaries, which would have become branches of the lead bank (of an existing multibank holding company), and de novo branching. The date of effectiveness for inter-state branching provisions was set to June 1, 1997. States could "opt in early" or "opt out" by passing state laws any time between September 1994 and 1 June 1997. By opting out, states would not have allowed cross-border branching at all. Conversely, by opting in early, states had the possibility of imposing limitations and restrictions. Therefore, while opening the way to inter-state branching, the Act gave states considerable leeway in how to implement it.

States could set a range of stricter provisions. They could set a minimum age requirement for the institution, not to exceed 5 years. Equally, they could decrease the statewide deposit cap, set in the Act to 30\%. Finally, regarding de novo branching and on the acquisition of individual branches provisions, states needed, if willing, to explicitly opt in. Overall, states could choose to grant cross-border activities only if the home state

\footnotetext{
${ }^{15}$ Intra-state operations are those taking place within the bank's home state borders, while inter-state operations are those across. With banking it requires the establishment or acquisition of a separate charter. With branching, the establishment or acquisition of a branch office which is not separately chartered or capitalized.
} 
of the bank willing to do them was also setting similar provisions (reciprocity clause). Clearly, setting stricter provisions relative to the ones contained in the original Act would have erected anti-competitive barriers and restricted entry. As reported by Johnson and Rice (2008) and Rice and Strahan (2010), between 1994 and 2005, states gradually moved towards a relaxation of the constraints. However, changes were not uniform, and, at the same point in time, some states were more deregulated than others.

We construct a state-year specific "openness index" (Index $\left.x_{j t}\right)$ based on how many provisions each state set in line with the Act in the period $1994-2005$, ranging from 0 to 5 (with 0 denoting the least open environment, and 5 the most open). The index is reported in Table 2, together with the dates at which states changed their legislation. We then use the constructed openness index as an instrument for the deposit rate $r_{j t}^{D}$. By allowing entry of out-of-state banks, the relaxation of branching restrictions created an increase in bank demand (i.e. competition) for deposits. This is likely to have brought an increase in deposit rates. We expect therefore that deposit rates are positively associated with the index.

The first column in Table 3 presents results of the regression of the deposit rate $r_{j t}^{D}$ on the explanatory variables $x_{j t}$ and the openness index Index $x_{j t}$. We refer to this regression as the "preliminary regression". We find that the effect of Index $x_{j t}$ on $r_{j t}^{D}$ is positive and statistically significant at $5 \%$. This confirms that to a higher Index $x_{j t}$ corresponds a higher level of competition, and this forces banks to increase the interest rate offered on their deposit accounts. Note that controlling for state and time effects which are included in $x_{j t}$, we identify the effect of $I_{n d e x_{j t}}$ from the fact that the relaxation of the restrictions did not happen at the same time in the different states.

In our setting, deposit rate $r_{j t}^{D}$ is interacted with the $S a v_{j t}$ and CustOwn $n_{j t}$ dummies. The endogenous variables are therefore three: $r_{j t}^{D}, r_{j t}^{D} \times S a v_{j t}$, and $r_{j t}^{D} \times C u s t O w n_{j t}$. To have an appropriate set of instruments, we follow Wooldridge (2010): We obtain the fitted values $\hat{r}_{j t}^{D}$ from the preliminary regression, and interact them with the $\operatorname{Sav}_{j t}$ and CustOwn $n_{j t}$ dummies. Our set of instruments is then composed by $\left\{\operatorname{Index}_{j t}, \hat{r}_{j t}^{D} \times \operatorname{Sav}_{j t}\right.$, $\left.\hat{r}_{j t}^{D} \times C u s t O w n_{j t}\right\}$. 


\section{Estimation Results}

For reference purposes, we first present the results derived from the multinomial logit specification, in Table 3. We then present the results of our full, random coefficients logit model, in Table 4.

\subsection{Multinomial Logit Model}

When no random coefficients are considered, the equation to be brought to the data simplifies to:

$$
\ln \left(s_{j t}\right)-\ln \left(s_{0 t}\right)=\alpha r_{j t}^{D}+\alpha^{S a v}\left(r_{j t}^{D} \times \operatorname{Sav}_{j t}\right)+\alpha^{\text {CustOwn }}\left(r_{j t}^{D} \times C u s t O w n_{j t}\right)+x_{j t} \beta+\xi_{j t}
$$

for which $\theta=\left(\alpha, \alpha^{\text {Sav }}, \alpha^{\text {CustOwn }}, \beta\right)$ can be readily estimated. We do so using 2SLS, first

regressing $r_{j t}^{D}, r_{j t}^{D} \times S a v_{j t}$, and $r_{j t}^{D} \times C u s t O w n_{j t}$ against observed bank characteristics $x_{j t}$ and Index $x_{j t}, \hat{r}_{j t}^{D} \times S a v_{j t}$, and $\hat{r}_{j t}^{D} \times C u s t O w n_{j t}$. Then we estimate (6) using the predicted variables from the first stage.

The second column in Table 3 presents the estimates of (6) using OLS. In case the deposit rate $r_{j t}^{D}$ is correlated with the error term $\xi_{j t}$, parameter estimates are biased and inconsistent. We expect the deposit rate to be endogenous in (6), so the OLS estimates are likely not to be reliable. Indeed, we find that the deposit rate coefficient $\alpha$ is not statistically significant, suggesting that depositors do not choose a bank account based on the deposit rate offered. The picture changes when we instrument $r_{j t}^{D}, r_{j t}^{D} \times S a v_{j t}$, and $r_{j t}^{D} \times C u s t O w n_{j t}$ by Index $j t, \hat{r}_{j t}^{D} \times$ Sav $_{j t}, \hat{r}_{j t}^{D} \times C u s t O w n_{j t}$. The results, which appear in the third column of Table 3 suggest, instead, that depositors react positively to the interest rate offered, and the effect is statistically significant.

The effect of the deposit rate on depositors' account choices is different depending on the bank type. Relative to commercial banks, depositors respond less to the deposit rate if the bank is a savings bank (both customer- and investor-owned). However, they do so to a lesser degree if the savings bank is customer-owned. Correspondingly, we also find 
that the coefficients of $\operatorname{Sav}_{j t}$ and CustOwn indicate that being a savings bank, especially if customer-owned, brings less value to the depositor relative to being a commercial bank. Interpreting all these coefficients as factor loadings in depositors' utility function, we can say that: 1) the deposit rate has more value if the bank offering it is commercial; 2) the value of being a savings bank is negative for depositors; 3) depositors perceive a difference between customer- and investor-owned savings banks, and the attribute of being customer-owned increases its value the higher is the deposit rate offered. Note that this latter point comes from the fact that the coefficient of CustOwn $n_{j t}$ is negative, while its interaction with $r_{j t}^{D}$ is positive.

The number of employees per branch, the size of the branch network, and the branch density, all enter positively in the utility function. This confirms earlier findings of Dick (2002, 2008), and Adams et al. (2007), which suggest that depositors prefer well-staffed branches, and large branch networks. Our results also indicate that depositors' utility falls if a bank is headquartered in another state. Indeed, if a bank operates out-of-state, it has weaker relationships with local depositors, and this reduces its perceived value to the customers, all other things being equal.

\subsection{Random Coefficients Logit Model}

We now present our estimates of the full random coefficients logit model. Following Knittel and Metaxoglou (2014), we run our estimation routine with 50 different sets of starting values for $\Sigma$, and in 49 cases we obtain convergence. In Table 4 , we present the estimates that produced the lowest value of our GMM objective function (see (13) in

the Appendix). The first column reports $\hat{\theta}$, while the second column reports $\hat{\Sigma}$, together with the standard errors. As discussed in Section 3, estimates of $\theta$ measure the mean levels of tastes for deposit rate and other observed bank characteristics across consumers. Estimates of $\hat{\Sigma}$ give, instead, the heterogeneity of depositor preferences in these taste parameters.

We first note that the mean level of $\hat{\alpha}$ is larger than that indicated by the multinomial 
logit estimation. ${ }^{16}$ However, as in the multinomial logit case, we see that on average, depositors value a deposit rate less if the offering bank is savings, but to a lesser degree if the offering savings bank is also customer-owned. Also, we find that the estimates of the elements of $\Sigma$ corresponding to the deposit rate are large in magnitude and statistically significant. This indicates that there is considerable heterogeneity in depositors' valuations of the deposit rate, and of the deposit rate when the bank is a savings bank. Finally, similarly to the multinomial logit estimates, the attribute of being a savings bank, especially if with customer ownership, is found to lead, on average, to a lower utility for the depositor.

Relative to the taste for the number of employees per branch and for the size of the branch network, the results are in line with the multinomial logit estimates. Depositors prefer, on average, well-staffed branches, and large branch networks. Also, these valuations display minimal heterogeneity across depositors. As for branch density, we find, instead, that the taste is markedly heterogeneous across consumers, though the mean valuation is not statistically different from zero. Finally, the attribute of being a bank headquartered in another state negatively affects depositors' utility, but this effect is also not statistically significant.

Overall, these results confirm our multinomial logit model findings on depositors' tastes for deposit rate, and the savings bank and customer ownership attributes. Our interpretation for the finding on the savings bank attribute is the following. Having an account at a bank not only gives the ability to store value and gain interest in a liquid asset, it also enables a depositor to have a relationship with a bank. This, in turn, gives access to a range of services. For example, asking for a mortgage or a personal loan, or investing in the financial market. The choice of where to have a bank account is therefore likely to be related to the scope of additional services offered by a bank. As discussed in Section 2, savings banks still focus on mortgage lending almost exclusively. This means that the range of operations a depositor may find there is quite limited. Therefore, if the average depositor is interested in having a relationship with a bank that offers other

\footnotetext{
${ }^{16}$ Baltas and Doyle (2001) observe that such a difference is commonly found when comparing discrete choice models with and without taste heterogeneity.
} 
services than mortgage lending, he would derive a lower utility from having an account at a savings bank, relative to having it at a commercial bank. Additionally, it is also likely that this depositor is less responsive to changes in the deposit rate if the offering bank is a savings bank. This is the possible reason we observe that the valuation of the savings bank attribute is negative, and depositors' valuation of the deposit rate is lower if the offering bank is savings.

The most striking finding in Table 4 relates, however, to the customer ownership attribute. Firstly, depositors' average evaluation of "being customer-owned" is negative. Secondly, depositors value the deposit rate more if the savings bank offering it has customer ownership. The combination of these two elements implies that a customer-owned savings bank is preferred to an investor-owned savings banks for high levels of the deposit rate, all other things being equal. The model of bank behavior under investor- and customer-ownership that we present in the Appendix suggests that, relative to investorowned institutions, customer-owned banks should offer higher deposit rates. This is because their assumed objective is to maximize the sum of profits and customer surplus, which we show in the Appendix to result in just customer surplus being maximized. Therefore, we interpret the finding that depositors prefer customer-owned savings banks to investor-owned savings banks for a high levels of the deposit rate as an indication that depositors value the customer ownership attribute only if the deposit rate is high enough to be perceived as depositor surplus maximizing. If that is not the case, the overall effect on depositors' utility of being customer-owned is negative.

\subsection{Deposit Rate Elasticities}

Before discussing details of our policy experiment to assess the welfare impact of demutualization, we first measure to what extent bank accounts at commercial, investor-owned savings, and customer-owned savings banks are comparable and substitutable by depositors. It may be that the market is actually segmented, and little or no substitution occurs among bank accounts offered by the different bank types. 
We produce the own and cross deposit rate elasticities based on the estimates of the random coefficients logit model. Adapting Nevo (2000), the formula for the deposit rate elasticities is:

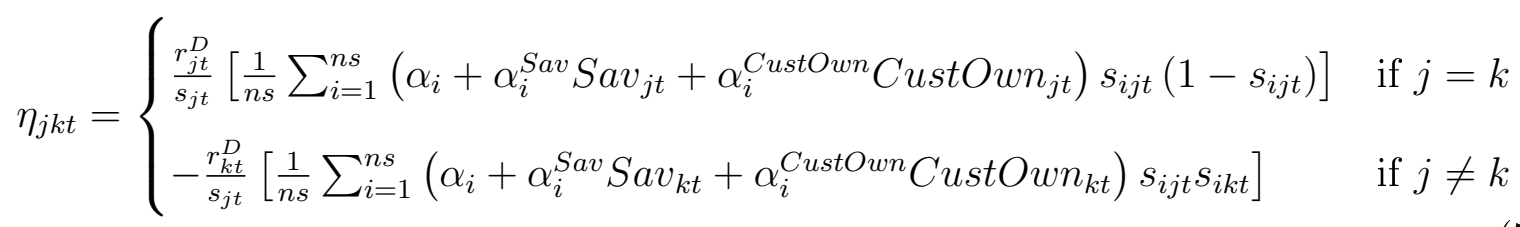

where $n s$ is the number of customers simulated in each market, in our case 100. Table 5 presents the resulting elasticities. Median own deposit rate elasticity is 2.67 for commercial banks, 2.86 for investor-owned savings banks, and 2.99 for customer-owned savings banks. At the 25 th and at the 75 th percentiles, banks with differing bank type display similar own deposit rate elasticities. This suggests that banks with differing type are confronted with similar deposit supply elasticities. However, the more distant one moves from the median, the more the distribution changes across banks with differing type. This results in different means. Cross deposit rate elasticities show that depositors substitute commercial banks primarily with other commercial banks and investor-owned savings banks. Symmetrically, depositors substitute investor-owned savings banks primarily with other investor-owned savings banks and commercial banks. Customer-owned savings banks appear, instead, to be relatively less substitutable with commercial and investor-owned savings banks. In any case, there does not appear a clear indication that any of the bank types cannot be substituted or is not comparable with the other bank types.

Comparing our findings to prior work on the U.S. banking system, our estimates are slightly larger than those obtained by Dick (2008). She estimates median own deposit rate elasticities of 1.77 in a nested logit model, and 2.33 in a multinomial logit model. Conversely, our estimates are smaller than those obtained by Adams et al. (2007) in urban markets. They find median own deposit elasticities of 3.47 for commercial banks and 4.27 for savings banks. They also find relatively lower substitution between commercial and savings banks. Note, however, that they do not differentiate savings banks between 
customer- and investor-owned. According to our results, considering customer-owned savings together with investor-owned savings banks may have reduced the cross deposit rate elasticity.

\section{Demutualizations and Depositor Welfare}

Section 4 provides evidence that bank ownership type matters when customers choose where to open a bank account. In fact, each depositor has a "taste" for the bank's attribute of "being customer-owned". Following the wave of demutualizations experienced by the US banking industry between 1994 and 2005 (as documented in Figure 3), we examine whether such events are beneficial to depositors or not. To do so, we estimate the welfare change that depositors would experience under a policy experiment in which all customerowned savings banks are assumed to demutualize. ${ }^{17}$ To conduct this experiment, we define as situation " 0 " the status quo scenario, in which customer-owned savings banks continue to operate. By contrast, situation " 1 " is our counterfactual scenario, in which all customer-owned savings are assumed to demutualize, and become investor-owned savings banks. Accordingly, $r_{j t}^{D, 0}$ and $x_{j t}^{0}$ are bank $j$ 's deposit rate and other characteristics in situation " 0 ", while $r_{j t}^{D, 1}$ and $x_{j t}^{1}$ are $j$ 's deposit rate and other characteristics in situation "1".

We measure the change in depositor welfare between situations " 0 " and "1" using (expected) compensating variation. This is the money amount that should be taken from a depositor's total income after demutualization to equate his or her utilities in the status quo and counterfactual scenarios.

We proceed as follows. As in Section 3, we normalize financial variables by dividing them by deposit size. We further assume that the compensating variation is a constant and uniform ratio of deposit size for all customers. Adapting Bockstael and McConnell (2007, chapter 5), we can then implicitly define the normalized compensating variation

\footnotetext{
${ }^{17}$ In this experiment we ignore all transaction and transitional costs, so our results should be interpreted in this light.
} 
$\widetilde{C V}$ of a change from $r_{j t}^{D, 0}$ to $r_{j t}^{D, 1}$ and from $x_{j t}^{0}$ to $x_{j t}^{1}$ by the following equation:

$$
\begin{aligned}
& \max _{j \in J}\left[\alpha_{i}\left(\tilde{y}+r_{j t}^{D, 0}\right)+A_{j t}^{0}+x_{j t}^{0} \beta_{i}+\xi_{j t}^{0}+\varepsilon_{i j t}\right]= \\
& \max _{j \in J}\left[\alpha_{i}\left(\tilde{y}+r_{j t}^{D, 1}-\widetilde{C V}\right)+A_{j t}^{1}+x_{j t}^{1} \beta_{i}+\xi_{j t}^{1}+\varepsilon_{i j t}\right]
\end{aligned}
$$

where:

$$
\begin{aligned}
& A_{j t}^{0}=\alpha_{i}^{S a v}\left(r_{j t}^{D, 0} \times S a v_{j t}^{0}\right)+\alpha_{i}^{\text {CustOwn }}\left(r_{j t}^{D, 0} \times C u s t O w n_{j t}^{0}\right) \\
& A_{j t}^{1}=\alpha_{i}^{S a v}\left(r_{j t}^{D, 1} \times S a v_{j t}^{1}\right)+\alpha_{i}^{\text {CustOwn }}\left(r_{j t}^{D, 1} \times \text { CustOwn } n_{j t}^{1}\right)
\end{aligned}
$$

and $\widetilde{C V}$ is the normalized compensating variation. If $\widetilde{C V}$ is positive, depositor $i$ experiences an increase in utility when all customer-owned savings banks are demutualized.

Since both $\tilde{y}$ and $\widetilde{C V}$ are constant across maximizations, we can simplify the previous equation to:

$$
\begin{array}{r}
\max _{j \in J}\left[\alpha_{i} r_{j t}^{D, 0}+A_{j t}^{0}+x_{j t}^{0} \beta_{i}+\xi_{j t}^{0}+\varepsilon_{i j t}\right]= \\
-\alpha_{i} \widetilde{C V}+\max _{j \in J}\left[\alpha_{i} r_{j t}^{D, 1}+A_{j t}^{1}+x_{j t}^{1} \beta_{i}+\xi_{j t}^{1}+\varepsilon_{i j t}\right]
\end{array}
$$

Solving for $\tilde{C V}$, we obtain:

$$
\begin{aligned}
\widetilde{C V} & =\frac{1}{\alpha_{i}}\left(\max _{j \in J}\left[\alpha_{i} r_{j t}^{D, 1}+A_{j t}^{1}+x_{j t}^{1} \beta_{i}+\xi_{j t}^{1}+\varepsilon_{i j t}\right]\right. \\
& \left.-\max _{j \in J}\left[\alpha_{i} r_{j t}^{D, 0}+A_{j t}^{0}+x_{j t}^{0} \beta_{i}+\xi_{j t}^{0}+\varepsilon_{i j t}\right]\right)
\end{aligned}
$$

Then, as in Nevo (2003), we compute its expected value as:

$$
\mathbb{E}(\widetilde{C V})=\int \frac{1}{\alpha_{i}}\left[V\left(r_{j t}^{D, 1}, x_{j t}^{1}\right)-V\left(r_{j t}^{D, 0}, x_{j t}^{0}\right)\right] d F\left(\alpha_{i}, \beta_{i}\right)
$$


with

$$
\begin{gathered}
V\left(r_{j t}^{D, 1}, x_{j t}^{1}\right)=\ln \left(\sum_{j=1}^{J} \exp \left(\alpha_{i} r_{j t}^{D, 1}+\alpha_{i}^{S a v}\left(r_{j t}^{D, 1} \times S a v_{j t}^{1}\right)+\alpha_{i}^{C u s t O w n}\left(r_{j t}^{D, 1} \times C u s t O w n_{j t}^{1}\right)+x_{j t}^{1} \beta_{i}+\xi_{j t}^{1}\right)\right) \\
V\left(r_{j t}^{D, 0}, x_{j t}^{0}\right)=\ln \left(\sum_{j=1}^{J} \exp \left(\alpha_{i} r_{j t}^{D, 0}+\alpha_{i}^{S a v}\left(r_{j t}^{D, 0} \times S a v_{j t}^{0}\right)+\alpha_{i}^{C u s t O w n}\left(r_{j t}^{D, 0} \times C u s t O w n_{j t}^{0}\right)+x_{j t}^{0} \beta_{i}+\xi_{j t}^{0}\right)\right) \\
d F\left(\alpha_{i}, \beta_{i}\right)=d P_{v}^{*}(v)
\end{gathered}
$$

The estimate of $E(\widetilde{C V})$ depends crucially on how the deposit rates and bank attributes change from situation "0" to "1". We consider two cases. In the first, demutualized banks offer the same deposit rate as when they were customer-owned, and only lose the attribute of "being customer-owned". In the second case, on top of losing the attribute of "being customer-owned", newly demutualized investor-owned savings banks offer a different rate than before. We assume they offer the mean rate of other investor-owned savings banks operating in their market. ${ }^{18}$

Since $E(\widetilde{C V})$ represents the normalized expected compensating variation, we obtain a non-normalized expected compensated variation multiplying $E(\widetilde{C V})$ by the average dollar quantity deposited in each market $t$. Table 6 presents the percentiles of the annual per-depositor non-normalized expected compensating variation for each market $t$ in 2005 dollars. We first consider the estimates across all markets. If customer-owned savings banks demutualized and they offered the deposit rate offered by other investor-owned savings banks, every depositor would gain, on average, more than one dollar (\$1.14) per market (i.e. state-year). This amount reduces to 36 cents if demutualized banks kept offering the same deposit rate they offered when they were customer-owned. In both cases, however, the distribution across markets suggests that a demutualization of customerowned savings banks would increase depositors' utility. Only in the lowest quartile (see the $10 \%$ and $25 \%$ columns of Table 6 ) do we find negative expected compensating variation. This suggests that the complete demutualization of all customer-owned savings banks

\footnotetext{
${ }^{18}$ When no investor-owned savings bank is operating in the same market (44 cases), we assume demutualized banks offer the mean deposit rate computed across all investor-owned savings banks in the same year.
} 
would harm depositor welfare in a minority of cases.

We then differentiate markets by year and importance of customer-owned savings banks. To assess the importance of customer-owned savings banks in each market, we compute the proportion of deposits managed by customer-owned savings banks. We then distinguish markets depending on which quartile they fall in the year-specific distribution. For a sense of the relative importance of customer-owned savings banks, in 2005 customerowned savings banks managed $6 \%$ of the total mass of deposits in states in the top quartile, while they managed $0 \%$ in states in the bottom quartile.

Table 6 reports both sets of comparisons. Comparing the estimates of the markets in 1994 with those in 2005, we find that the benefits of demutualization would be greater in the latter. Moreover, Table 6 makes clear that the effect of the demutualization would be very sizeable in markets with a relatively high presence of customer-owned savings, while it would be marginal in states with a low presence of these institutions. In markets with relatively high presence, a depositor would gain an average of 2 dollars per market if, following demutualization, customer-owned savings offered the deposit rate of other investor-owned savings.

Following Nevo (2003), we can compute an aggregate welfare effect. This is achieved by multiplying the non-normalized expected compensated variation by the size of the relevant market - i.e. the total number of bank account choices $M_{t}$. Table 7 presents the estimates (in 2005 millions of dollars per market). Focusing on the entire sample, we find that the demutualization would increase total welfare by, on average, $\$ 6$ million per market if former customer-owned savings still offered their pre-demutualization deposit rate, or almost $\$ 22$ million if they offered the mean rate offered by other investor-owned savings banks. Differentiating by year and by presence of customer-owned savings does not affect the order of magnitude. Still, the effects are more sizeable the higher is the presence of customer-owned savings banks.

In Section 4 we found that customer-owned savings banks are preferred to investorowned savings banks when they offer high deposit rates. We argued that this is because depositors value the customer-owned attribute only if they perceive that the bank is truly 
maximizing depositor surplus. Overall, Tables 6 and 7 suggest that a demutualization of the entire customer-owned banking sector would increase depositors' welfare (all other things being equal, and ignoring transaction and transitional costs). In the scenario in which demutualized savings banks only lose the "customer-ownership" attribute, an increase in depositor welfare after the demutualization indicates that the deposit rate offered before the policy intervention is not high enough to countervail the negative effect of "being customer-owned". So, following our earlier intepretation, the reason a complete demutualization would be beneficial for depositors is that depositors currently perceive customer-owned savings banks as not remunerating deposits enough, i.e. as not genuinely maximizing customer surplus in practice.

The scenario in which demutualized savings banks change the deposit rate offered reinforces the effect. In fact, Tables 6 and 7 indicate that depositors' welfare gain would be even larger if demutualized banks offered a deposit rate in line with other investorowned savings banks. Figure 4 plots the evolution of the deposit rates paid by commercial, investor-owned savings, and customer-owned savings banks from 1994 to 2005. The rate offered by investor-owned savings banks is very similar to the one offered by customerowned savings banks, but is often higher. This means that if newly demutualized savings banks offered a deposit rate in line with other investor-owned savings banks, their rate would often be larger than that offered when they were customer-owned. Therefore, following demutualization, depositors would enjoy a higher interest rate, which ultimately leads to a higher welfare.

\section{Conclusions}

U.S. savings banks arose in the nineteenth century as a means of promoting saving and home ownership among the working and lower classes. Originally customer-owned, in recent decades many have converted to investor ownership. Since customer ownership is typically associated with consumer surplus maximization, it is natural to consider the 
implications of demutualizations for customer welfare. This paper provides an answer using structural econometric techniques.

Using data on U.S. commercial and savings banks from 1994 to 2005, we have estimated a discrete choice model of bank account choice with random coefficients. In particular, we have allowed for the attribute of "being savings" and "being customerowned" to change depositors' evaluations of banks, and of the deposit rates they offer. Our estimates indicate that depositors value customer- and investor-owned savings banks differently (and each differently to commercial banks). In particular, customer-owned savings are preferred to investor-owned savings banks for high levels of the deposit rate offered. In theory, as customer-ownership is associated with customer surplus maximization, customer-owned banks should offer higher deposit rates. In light of this, we interpret our findings as an indication that depositors prefer customer-owned savings banks to investor-owned savings banks only if they perceive that such banks are maximizing customer surplus in practice.

Finally, we have measured the welfare change that depositors would experience under a policy experiment in which all customer-owned savings banks are assumed to demutualize. We found that if demutualized banks offered a deposit rate in line with other investorowned savings banks, every depositor would gain, on average, more than one dollar $(\$ 1.14)$ every year. Aggregating this gain across all depositors in the same state and year implies an average welfare gain of $\$ 22$ million for each state and year. Overall, these figures suggest that depositors would, on average, benefit from a demutualization of customer-owned savings banks. 


\section{References}

[1] Adams, R., Brevoort, K. and E. Kiser, 2007, "Who Competes with Whom? The Case of Depository Institutions", Journal of Industrial Economics, LV(1), March, $141-167$.

[2] Amel, D. and M. Starr-McCluer, 2002, "Market Definition in Banking: Recent Evidence", Antitrust Bulletin, 47(1), 63-89.

[3] Ayadi, R., Llewellyn, D., Schmidt, R., Arbak, E. and W. De Groen, 2010, Investigating Diversity in the Banking Sector in Europe: Key Developments, Performance and Role of Cooperative Banks, Centre for European Policy Studies, Brussels.

[4] Baltas, G. and P. Doyle, 2001, "Random Utility Models in Marketing Research: A Survey", Journal of Business Research, 51, 115-125.

[5] Barth, J.R., T. Li, and W. Lu, 2010, "Bank regulation in the United States", CESifo Economic Studies, 56, 112-140.

[6] Berry, S., 1994, "Estimating Discrete-Choice Models of Product Differentiation", RAND Journal of Economics, 25, 242-262.

[7] Berry, S., Levinsohn, J. and A. Pakes, 1995, "Automobile Prices in Market Equilibrium", Econometrica, 63, 841-890.

[8] Berry, S., Linton, O. and A. Pakes, 2004, "Limit Theorems for Estimating the Parameters of Differentiated Product Demand Systems", Review of Economic Studies, 71(3), July, 613-654.

[9] Chaddad, F. and M. Cook, 2004, "The Economics of Organization Structure Changes: A US Perspective on Demutualization," in: Annals of Public and Cooperative Economics, 75(4), 575-594.

[10] Cole, R. A., and H. Mehran, 1998, "The effect of changes in ownership structure on performance: evidence from the thrift industry", Journal of Financial Economics, 50, 291-317. 
[11] Cordell, L. R., Macdonald G. D. and M. E. Wohar, 1993, "Corporate ownership and the thrift crisis", Journal of Law and Economics, 36, 719-756.

[12] Crawford, G. S., Pavanini N. and F. Schivardi, 2017, Asymmetric information and imperfect competition in lending markets, April.

[13] Dick, A., 2002, Demand Estimation and Consumer Welfare in the Banking Industry, November.

[14] Dick, A., 2008, "Demand Estimation and Consumer Welfare in the Banking Industry", Journal of Banking \& Finance, 32, 1661-1676.

[15] Dodds, W., Monroe, K. and D. Grewal, 1991, "Effects of Price, Brand, and Store Information on Buyers' Product Evaluations", Journal of Marketing Research, XXVIII, August, 307-319.

[16] Esty, B. C., 1997, "Organizational form and risk taking in the savings and loan industry", Journal of Financial Economics, 44, 25-55.

[17] Federal Deposit Insurance Corporation, 1997, An Examination of the Banking Crises of the 1980s and Early 1990s, in: History of the Eighties - Lessons for the Future, December.

[18] Fonteyne, W., 2007, Cooperative Banks in Europe - Policy Issues, IMF Working Paper 07/159.

[19] Hadaway, B. L., and S. C. Hadaway, 1981, "An analysis of the performance characteristics of converted savings and loan associations", Journal of Financial Research, 4, 195-206.

[20] Hansmann, H., 1996, The Ownership of Enterprise, Harvard University Press, Cambridge, MA.

[21] Ho, K. and J. Ishii, 2011, "Location and Competition in Retail Banking", International Journal of Industrial Organization, 29(5), 537-546.

[22] Johnson, R. and K. Olberts, 1996, Using Conjoint Analysis in Pricing Studies: Is One Price Variable Enough?, Sawtooth Software Research Paper Series. 
[23] Johnson, C. and T. Rice, 2008, "Assessing a Decade of Interstate Bank Branching", The Washington and Lee Law Review, 65(1), 73-127.

[24] Kane, E. J., 1996, "De jure interstate banking: Why only now?", Journal of Money, Credit, and Banking, 28(2), 141-161.

[25] Kiser, E. K., 2002, "Household Switching Behavior at Depository Institutions: Evidence from Survey Data", Antitrust Bulletin, 47(4), 619-640.

[26] Knittel, C. and K. Metaxoglou, 2014, "Estimation of Random-Coefficient Demand Models: Two Empiricists' Perspective", Review of Economics and Statistics, 96(1), March, 34-59.

[27] Kroszner, R. S., and P. E. Strahan, 1996, "Regulatory incentives and the thrift crisis: dividends, mutual-to-stock conversions, and financial distress", Journal of Finance, $51,1285-1320$.

[28] Masulis R.W., 1987, "Changes in ownership structure: conversions of mutual savings and loans to stock charter", Journal of Financial Economics, 18, 29-59.

[29] Meade, R., 2014, Incentives, Efficiency and Quality in Regulated Monopolies under Customer Ownership, July.

[30] Mishkin, F. S., and S. Eakins, 2012, Financial Markets and Institutions, 7th Edition, Pearson Education.

[31] Molnar, J., Nagy, M. and C. Horvath, 2006, A Structural Empirical Analysis of Retail Banking Competition: The Case of Hungary, November.

[32] Moral, M. and J. Jaumandreu, 2007, "Automobile Demand, Model Cycle and Age Effects", Spanish Economic Review, 9(3), 193-218.

[33] Nakane, M., Alencar, L. and F. Kanczuk, 2006, Demand for Bank Services and Market Power in Brazilian Banking, Banco Centrale Do Brasil, June.

[34] Nevo, A., 2000, "A Practitioner's Guide to Estimation of Random-Coefficients Logit Models of Demand", Journal of Economics \& Management Strategy, 9(4), Winter, 513-548. 
[35] Nevo, A., 2001, "Measuring Market Power in the Ready-to-Eat Cereal Industry", Econometrica, 69(2), March, 307-342.

[36] Nevo, A., 2003, "New products, quality changes and welfare measures computed from estimated demand systems", The Review of Economics and Statistics, 85(2), $266-275$.

[37] Nevo, A. and K. Hatzitaskos, 2006, Why Does the Average Price Paid Fall During High Demand Periods?, July.

[38] Perez Montes, C., 2014, "The effect on competition of banking sector consolidation following the financial crisis of 2008", Journal of Banking \& Finance, 43, 124-136.

[39] Radecki, L., 1998, "Small Expanding Geographic Reach of Retail Banking Markets", Federal Reserve Bank of New York Economic Policy Review, 4, 15-34.

[40] Raghavarao, D., Wiley, J. and P. Chitturi, 2010, Choice-Based Conjoint Analysis: Models and Designs, CRC Press, Taylor \& Francis Group.

[41] Rice, T., and P. E. Strahan, 2010, "Does Credit Competition Affect Small-Firm Finance", Journal of Finance, 65(3), 861-889.

[42] Train, K., 2009, Discrete Choice Methods with Simulation, Cambridge University Press.

[43] Wilcox, J., 2006, Credit Union Conversions to Banks: Facts, Incentives, Issues and Reforms, Filene Research Institute.

[44] Williams, H. C., 2006, Federal Banking Law \& Regulations: A Handbook for Lawyers, American Bar Association, December.

[45] Wooldridge, J., 2010, Econometric Analysis of Cross Section and Panel Data, 2nd Edition, MIT Press Books. 


\section{Figures}

Figure 1: Classification of U.S. Bank Types

\begin{tabular}{c|c|c|c|c} 
& \multicolumn{3}{|c|}{ Thrifts* } & Commercial \\
Banks*
\end{tabular}

${ }^{*}$ Can be further distinguished by state or federal charter.

Figure 2: Number of banks in the U.S. by ownership type

This Figure plots the quarterly evolution of the number of banks operating in the U.S. differentiating by commercial, investor-owned savings, and customer-owned savings banks. The data are from the FDIC, Statistics on Depository Institutions.

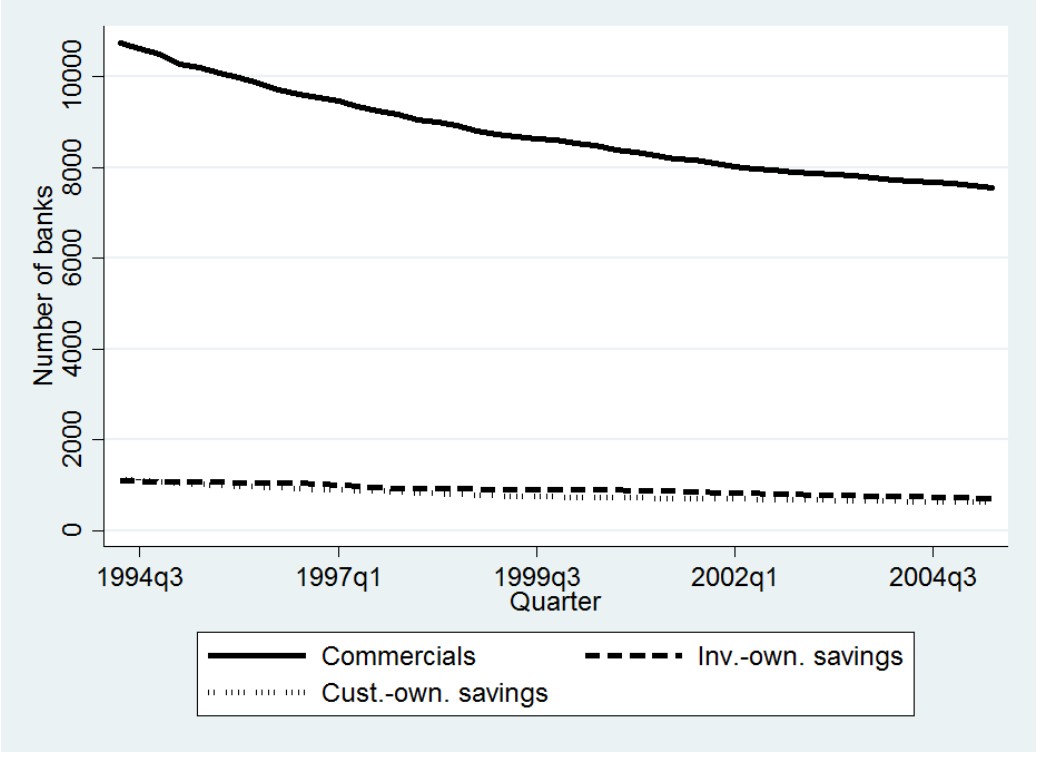




\section{Figure 3: Number of demutualizations and \% to total}

This Figure plots the quarterly evolution of the number of conversions of U.S. savings banks from customer to investor ownership. The data are from the FDIC, Statistics on Depository Institutions.

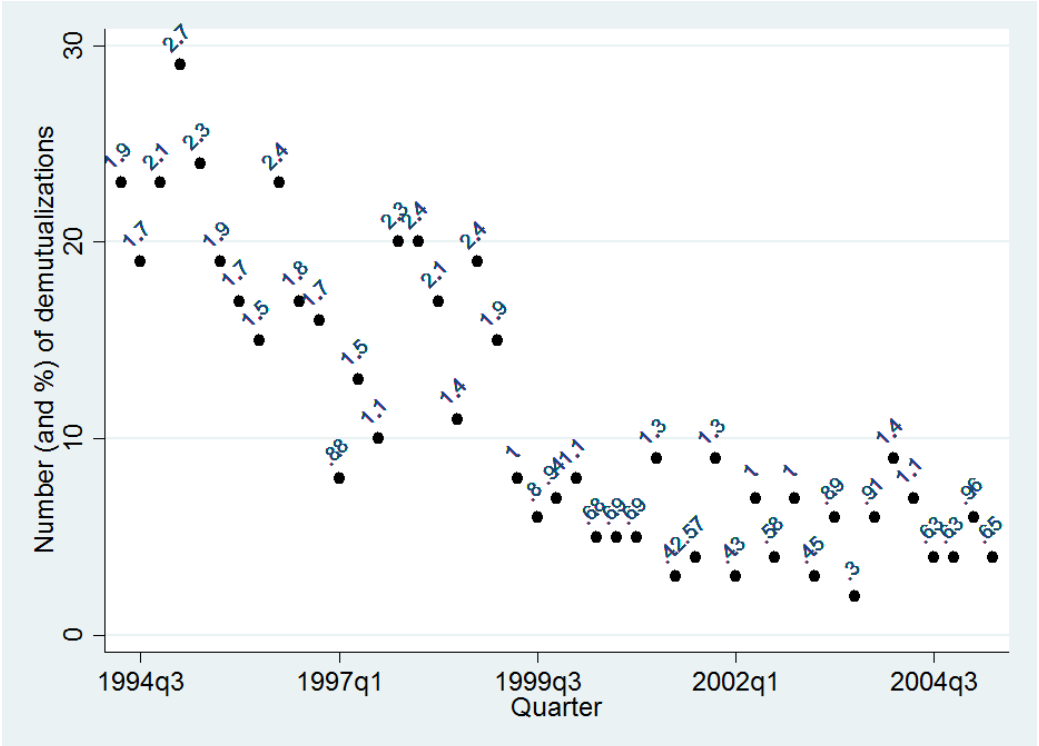

Figure 4: Deposit rate by bank ownership type

This Figure plots the quarterly evolution of the average deposit rate, differentiating by commercial, investor-owned savings, and customer-owned savings banks. We first obtain quarterly interest rates dividing the domestic deposit interest payments realized during a quarter by the amount of domestic deposits outstanding at the end of the previous quarter. Then, we obtain the yearly interest rates, promised at a given point in time, by compounding the gross quarterly interest rates realized in the subsequent four quarters and subtracting one. We average these rates across banks of the same type, and compute $95 \%$ confidence intervals. The data are from the FDIC, Statistics on Depository Institutions.

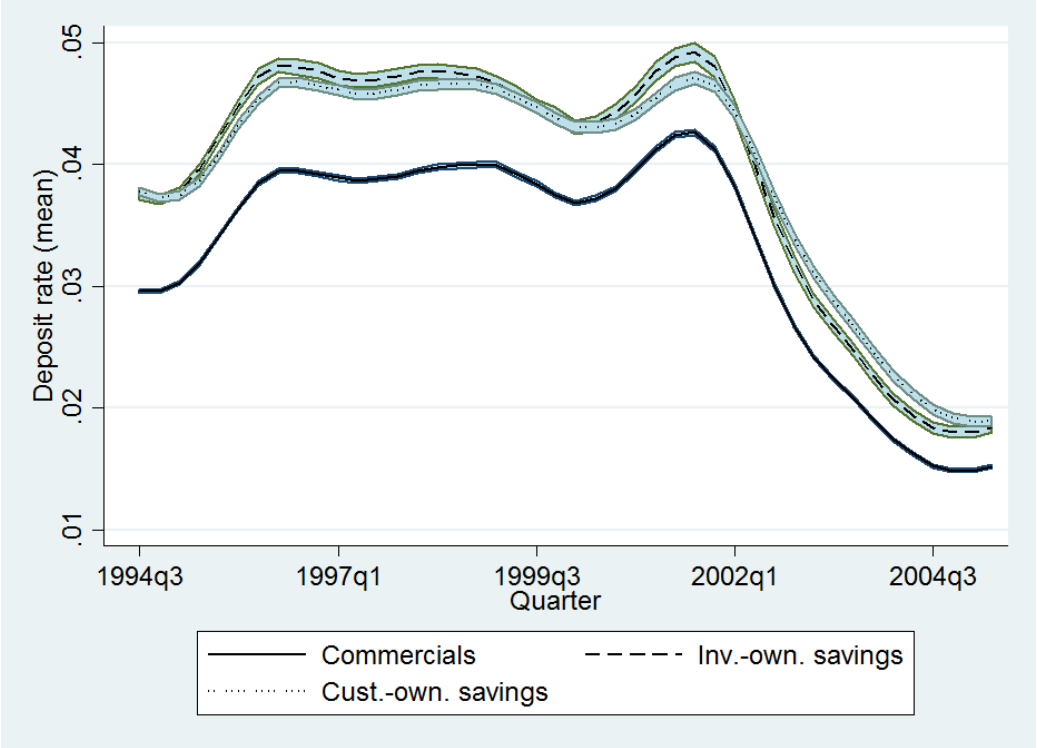




\section{Tables}

\section{Table 1: Summary statistics by bank type and year}

This Table presents the summary statistics of the sample used for the estimations, distinguishing by bank type and year. $s_{j t}$ is bank $j$ 's market share in market $t, r_{j t}^{D}$ is the deposit rate offered, Empl per branch j $_{j t}$ is the $\log$ of its number of employees per branch, Number of branches ${ }_{j t}$ is the log of its number of branches, Branch density ${ }_{j t}$ is the log of its branch density, and Out of State bank $k_{j t}$ captures whether $j$ 's headquarters are located out of the state being considered. The data are from the FDIC, Statistics on Depository Institutions.

\begin{tabular}{|c|c|c|c|c|c|c|c|c|c|}
\hline & & & All ye & & & & & & \\
\hline Type & Bank Characteristic & $\mathrm{N}^{\circ}$ Obs. & Mean & Med. & SD & & & & \\
\hline & $s_{j t}$ & 42,123 & 0.004 & 0.001 & 0.014 & & & & \\
\hline & $r_{j t}^{D}$ & 42,123 & 0.032 & 0.034 & 0.012 & & & & \\
\hline Commercial & Empl per branch ${ }_{j t}$ & 42,123 & 2.780 & 2.741 & 0.463 & & & & \\
\hline banks & Number of branches ${ }_{j t}$ & 42,123 & 1.782 & 1.386 & 1.493 & & & & \\
\hline & Branch density ${ }_{j t}$ & 42,123 & -9.406 & -9.545 & 1.481 & & & & \\
\hline & Out of State bank $k_{j t}$ & 42,123 & 0.054 & 0.000 & 0.226 & & & & \\
\hline & $s_{j t}$ & 5,146 & 0.006 & 0.002 & 0.014 & & & & \\
\hline Investor- & $r_{j t}^{D}$ & 5,146 & 0.038 & 0.041 & 0.013 & & & & \\
\hline owned & Empl per branch ${ }_{j t}$ & 5,146 & 2.801 & 2.773 & 0.504 & & & & \\
\hline savings & Number of branches ${ }_{j t}$ & 5,146 & 2.613 & 2.398 & 1.471 & & & & \\
\hline banks & Branch density $_{j t}$ & 5,146 & -8.344 & -8.494 & 1.609 & & & & \\
\hline & Out of State bank $k_{j t}$ & 5,146 & 0.141 & 0.000 & 0.348 & & & & \\
\hline & $s_{j t}$ & 3,063 & 0.003 & 0.001 & 0.005 & & & & \\
\hline Customer- & $r_{j t}^{D}$ & 3,063 & 0.038 & 0.041 & 0.011 & & & & \\
\hline owned & Empl per branch ${ }_{j t}$ & 3,063 & 2.755 & 2.752 & 0.405 & & & & \\
\hline savings & Number of branches ${ }_{j t}$ & 3,063 & 1.653 & 1.609 & 0.834 & & & & \\
\hline banks & Branch density ${ }_{j t}$ & 3,063 & -8.630 & -8.764 & 1.398 & & & & \\
\hline & Out of State bank $k_{j t}$ & 3,063 & 0.017 & 0.000 & 0.129 & & & & \\
\hline & & & 199 & & & & 200 & & \\
\hline Type & Bank Characteristic & $\mathrm{N}^{\circ}$ Obs. & Mean & Med. & SD & $\mathrm{N}^{\circ}$ Obs. & Mean & Med. & $\mathrm{SD}$ \\
\hline & $s_{j t}$ & 4,570 & 0.003 & 0.001 & 0.011 & 2,851 & 0.006 & 0.001 & 0.018 \\
\hline & $r_{j t}^{D}$ & 4,570 & 0.034 & 0.034 & 0.008 & 2,851 & 0.023 & 0.023 & 0.005 \\
\hline Commercial & Empl per branch ${ }_{j t}$ & 4,570 & 2.870 & 2.833 & 0.501 & 2,851 & 2.723 & 2.694 & 0.428 \\
\hline banks & Number of branches $s_{j t}$ & 4,570 & 1.321 & 1.099 & 1.103 & 2,851 & 2.350 & 1.792 & 1.836 \\
\hline & Branch density ${ }_{j t}$ & 4,570 & -9.747 & -9.868 & 1.473 & 2,851 & -9.002 & -9.293 & 1.470 \\
\hline & Out of Statebank $k_{j t}$ & 4,570 & 0.001 & 0.000 & 0.033 & 2,851 & 0.121 & 0.000 & 0.326 \\
\hline & $s_{j t}$ & 556 & 0.005 & 0.002 & 0.009 & 308 & 0.008 & 0.002 & 0.017 \\
\hline Investor- & $r_{j t}^{D}$ & 556 & 0.042 & 0.042 & 0.006 & 308 & 0.025 & 0.025 & 0.005 \\
\hline owned & Empl per branch ${ }_{j t}$ & 556 & 2.801 & 2.797 & 0.453 & 308 & 2.865 & 2.798 & 0.480 \\
\hline savings & Number of branches $s_{j t}$ & 556 & 2.482 & 2.303 & 1.322 & 308 & 2.991 & 2.639 & 1.725 \\
\hline banks & Branch density $_{j t}$ & 556 & -8.426 & -8.541 & 1.498 & 308 & -8.063 & -8.128 & 1.787 \\
\hline & Out of State bank $k_{j t}$ & 556 & 0.110 & 0.000 & 0.313 & 308 & 0.195 & 0.000 & 0.397 \\
\hline & $s_{j t}$ & 410 & 0.002 & 0.001 & 0.004 & 165 & 0.003 & 0.001 & 0.006 \\
\hline Customer- & $r_{j t}^{D}$ & 410 & 0.041 & 0.041 & 0.005 & 165 & 0.025 & 0.025 & 0.005 \\
\hline owned & Empl per branch $_{j t}$ & 410 & 2.727 & 2.722 & 0.440 & 165 & 2.776 & 2.797 & 0.369 \\
\hline savings & Number of branches ${ }_{j t}$ & 410 & 1.522 & 1.609 & 0.823 & 165 & 1.880 & 1.792 & 0.924 \\
\hline banks & Branch density $y_{j t}$ & 410 & -8.832 & -8.957 & 1.397 & 165 & -8.490 & -8.674 & 1.379 \\
\hline & Out of State bank $k_{j t}$ & 410 & 0.007 & 0.000 & 0.085 & 165 & 0.036 & 0.000 & 0.188 \\
\hline
\end{tabular}


Table 2: Cronology of the states' bank branching provisions $1994-2005$

This Table presents the cronology of the bank branching provisions implemented by each state over the period 1994 - 2005, following the passing of the Riegle-Neal Act in 1994. The value is "1" if the provision has been implemented. Source: Johnson and Rice (2008).

$\begin{array}{cccccccc}\text { Openness } & \text { Effective } & \text { NO Min. } & \text { De Novo } & \text { Single Br. } & \text { Statewide } & \text { NO } \\ & \text { Index (w/o } & \text { Date } & \text { Age for } & \text { Branch } & \text { Acquisition } & \text { Dep. Cap } & \text { Recipr. }\end{array}$

\begin{tabular}{ccccc} 
Recipr.) & Target Inst. Allowed Allowed $\geq 30 \% \quad$ Clause \\
\hline \hline Alabama
\end{tabular}

\begin{tabular}{|c|c|c|c|c|c|c|c|}
\hline Alabama & 2 2(1) & $5 / 31 / 1997$ & 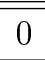 & 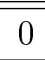 & 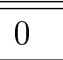 & $\bar{~} 1$ & $\bar{~} 1$ \\
\hline Alaska & $3(2)$ & $1 / 1 / 1994$ & 0 & 0 & 1 & 1 & 1 \\
\hline \multirow[t]{2}{*}{ Arizona } & $2(2)$ & $8 / 31 / 2001$ & 0 & 0 & 1 & 1 & 0 \\
\hline & $1(1)$ & $9 / 1 / 1996$ & 0 & 0 & 0 & 1 & 0 \\
\hline Arkansas & $1(0)$ & $6 / 1 / 1997$ & 0 & 0 & 0 & 0 & 1 \\
\hline California & $2(1)$ & $9 / 28 / 1995$ & 0 & 0 & 0 & 1 & 1 \\
\hline Colorado & $1(0)$ & $6 / 1 / 1997$ & 0 & 0 & 0 & 0 & 1 \\
\hline Connecticut & $3(3)$ & $6 / 27 / 1995$ & 0 & 1 & 1 & 1 & 0 \\
\hline Delaware & $2(1)$ & $9 / 29 / 1995$ & 0 & 0 & 0 & 1 & 1 \\
\hline $\mathrm{DC}$ & $5(4)$ & $6 / 13 / 1996$ & 1 & 1 & 1 & 1 & 1 \\
\hline Florida & $2(1)$ & $6 / 1 / 1997$ & 0 & 0 & 0 & 1 & 1 \\
\hline \multirow[t]{2}{*}{ Georgia } & $2(1)$ & $5 / 10 / 2002$ & 0 & 0 & 0 & 1 & 1 \\
\hline & $2(1)$ & $6 / 1 / 1997$ & 0 & 0 & 0 & 1 & 1 \\
\hline \multirow[t]{2}{*}{ Hawaii } & $5(4)$ & $1 / 1 / 2001$ & 1 & 1 & 1 & 1 & 1 \\
\hline & $2(1)$ & $6 / 1 / 1997$ & 0 & 0 & 0 & 1 & 1 \\
\hline Idaho & $1(1)$ & $9 / 29 / 1995$ & 0 & 0 & 0 & 1 & 0 \\
\hline \multirow[t]{2}{*}{ Illinois } & $4(4)$ & $8 / 20 / 2004$ & 1 & 1 & 1 & 1 & 0 \\
\hline & $2(1)$ & $6 / 1 / 1997$ & 0 & 0 & 0 & 1 & 1 \\
\hline \multirow[t]{2}{*}{ Indiana } & $3(3)$ & $7 / 1 / 1998$ & 0 & 1 & 1 & 1 & 0 \\
\hline & $4(4)$ & 6/1/1997 & 1 & 1 & 1 & 1 & 0 \\
\hline Iowa & $1(0)$ & $4 / 4 / 1996$ & 0 & 0 & 0 & 0 & 1 \\
\hline Kansas & $1(0)$ & 9/29/1995 & 0 & 0 & 0 & 0 & 1 \\
\hline \multirow[t]{3}{*}{ Kentucky } & $1(1)$ & $3 / 22 / 2004$ & 1 & 0 & 0 & 0 & 0 \\
\hline & $2(1)$ & $3 / 17 / 2000$ & 1 & 0 & 0 & 0 & 1 \\
\hline & $1(0)$ & $6 / 1 / 1997$ & 0 & 0 & 0 & 0 & 1 \\
\hline Louisiana & $2(1)$ & $6 / 1 / 1997$ & 0 & 0 & 0 & 1 & 1 \\
\hline Maine & $4(4)$ & $1 / 1 / 1997$ & 1 & 1 & 1 & 1 & 0 \\
\hline Maryland & $5(4)$ & 9/29/1995 & 1 & 1 & 1 & 1 & 1 \\
\hline Massachusetts & $3(3)$ & $8 / 2 / 1996$ & 0 & 1 & 1 & 1 & 0 \\
\hline Michigan & $4(4)$ & $11 / 29 / 1995$ & 1 & 1 & 1 & 1 & 0 \\
\hline Minnesota & $2(1)$ & $6 / 1 / 1997$ & 0 & 0 & 0 & 1 & 1 \\
\hline Mississippi & $1(0)$ & $6 / 1 / 1997$ & 0 & 0 & 0 & 0 & 1 \\
\hline Missouri & $1(0)$ & $9 / 29 / 1995$ & 0 & 0 & 0 & 0 & 1 \\
\hline \multirow[t]{2}{*}{ Montana } & $1(0)$ & $10 / 1 / 2001$ & 0 & 0 & 0 & 0 & 1 \\
\hline & $0(0)$ & $9 / 29 / 1995$ & \multicolumn{5}{|c|}{ Opt out } \\
\hline Nebraska & $1(0)$ & $5 / 31 / 1997$ & 0 & 0 & 0 & 0 & 1 \\
\hline Nevada & $2(1)$ & $9 / 29 / 1995$ & 0 & 0 & 0 & 1 & 1 \\
\hline
\end{tabular}




\begin{tabular}{|c|c|c|c|c|c|c|c|}
\hline State & $\begin{array}{c}\text { Openness } \\
\text { Index (w/o } \\
\text { Recipr.) }\end{array}$ & $\begin{array}{c}\text { Effective } \\
\text { Date }\end{array}$ & $\begin{array}{l}\text { NO Min. } \\
\text { Age for } \\
\text { Target Inst. }\end{array}$ & $\begin{array}{c}\text { De Novo } \\
\text { Branch } \\
\text { Allowed }\end{array}$ & $\begin{array}{c}\text { Single Br. } \\
\text { Acquisition } \\
\text { Allowed }\end{array}$ & $\begin{array}{c}\text { Statewide } \\
\text { Dep. Cap } \\
\geq 30 \%\end{array}$ & $\begin{array}{c}\text { NO } \\
\text { Recipr. } \\
\text { Clause }\end{array}$ \\
\hline New & $4(4)$ & $1 / 1 / 2002$ & 1 & 1 & 1 & 1 & 0 \\
\hline \multirow[t]{2}{*}{ Hampshire } & $3(3)$ & $8 / 1 / 2000$ & 0 & 1 & 1 & 1 & 0 \\
\hline & $1(0)$ & $6 / 1 / 1997$ & 0 & 0 & 0 & 0 & 1 \\
\hline New Jersey & $4(3)$ & $4 / 17 / 1996$ & 1 & 0 & 1 & 1 & 1 \\
\hline New Mexico & $2(1)$ & $6 / 1 / 1996$ & 0 & 0 & 0 & 1 & 1 \\
\hline New York & $3(2)$ & $6 / 1 / 1997$ & 0 & 0 & 1 & 1 & 1 \\
\hline North Carolina & $4(4)$ & $7 / 1 / 1995$ & 1 & 1 & 1 & 1 & 0 \\
\hline \multirow[t]{2}{*}{ North Dakota } & $3(3)$ & $8 / 1 / 2003$ & 1 & 1 & 1 & 0 & 0 \\
\hline & $1(1)$ & $5 / 31 / 1997$ & 1 & 0 & 0 & 0 & 0 \\
\hline Ohio & $5(4)$ & $5 / 21 / 1997$ & 1 & 1 & 1 & 1 & 1 \\
\hline \multirow[t]{2}{*}{ Oklahoma } & $3(3)$ & $5 / 17 / 2000$ & 1 & 1 & 1 & 0 & 0 \\
\hline & $1(0)$ & $5 / 31 / 1997$ & 0 & 0 & 0 & 0 & 1 \\
\hline \multirow[t]{2}{*}{ Oregon } & $2(1)$ & $7 / 1 / 1997$ & 0 & 0 & 0 & 1 & 1 \\
\hline & $3(2)$ & $2 / 27 / 1995$ & 0 & 0 & 1 & 1 & 1 \\
\hline Pennsylvania & $4(4)$ & $7 / 6 / 1995$ & 1 & 1 & 1 & 1 & 0 \\
\hline Rhode Island & $4(4)$ & $6 / 20 / 1995$ & 1 & 1 & 1 & 1 & 0 \\
\hline South Carolina & $2(1)$ & $7 / 1 / 1996$ & 0 & 0 & 0 & 1 & 1 \\
\hline South Dakota & $2(1)$ & $3 / 9 / 1996$ & 0 & 0 & 0 & 1 & 1 \\
\hline \multirow[t]{4}{*}{ Tennessee } & $3(3)$ & $3 / 17 / 2003$ & 0 & 1 & 1 & 1 & 0 \\
\hline & $3(3)$ & $7 / 1 / 2001$ & 0 & 1 & 1 & 1 & 0 \\
\hline & $2(2)$ & $5 / 1 / 1998$ & 0 & 0 & 1 & 1 & 0 \\
\hline & $1(1)$ & $6 / 1 / 1997$ & 0 & 0 & 0 & 1 & 0 \\
\hline \multirow[t]{2}{*}{ Texas } & $3(3)$ & $9 / 1 / 1999$ & 1 & 1 & 1 & 0 & 0 \\
\hline & $0(0)$ & $8 / 28 / 1995$ & & & Opt out & & \\
\hline \multirow[t]{2}{*}{ Utah } & $3(3)$ & $4 / 30 / 2001$ & 0 & 1 & 1 & 1 & 0 \\
\hline & $3(2)$ & $6 / 1 / 1995$ & 0 & 0 & 1 & 1 & 1 \\
\hline \multirow[t]{2}{*}{ Vermont } & $4(4)$ & $1 / 1 / 2001$ & 1 & 1 & 1 & 1 & 0 \\
\hline & $3(2)$ & $5 / 30 / 1996$ & 0 & 0 & 1 & 1 & 1 \\
\hline Virginia & $4(4)$ & $9 / 29 / 1995$ & 1 & 1 & 1 & 1 & 0 \\
\hline \multirow[t]{2}{*}{ Washington } & $3(3)$ & $5 / 9 / 2005$ & 0 & 1 & 1 & 1 & 0 \\
\hline & $2(1)$ & 6/6/1996 & 0 & 0 & 0 & 1 & 1 \\
\hline West Virginia & $3(3)$ & $5 / 31 / 1997$ & 1 & 1 & 1 & 0 & 0 \\
\hline Wisconsin & $2(1)$ & $5 / 1 / 1996$ & 0 & 0 & 0 & 1 & 1 \\
\hline Wyoming & $2(1)$ & $5 / 31 / 1997$ & 0 & 0 & 0 & 1 & 1 \\
\hline
\end{tabular}




\section{Table 3: "Preliminary regression" and Multinomial Logit results}

This Table presents the results of the "preliminary" regression, and of the multinomial logit model, estimated with OLS and IV. In the preliminary regression, the deposit rate $r_{j t}^{D}$ is a function of the explanatory variables $x_{j t}$ and the openness index Index $x_{j t}$. The fitted values of this regression are called $\hat{r}_{j t}^{D}$. The instruments used in the IV estimation of the multinomial logit model are $\operatorname{Index}_{j t}, \hat{r}_{j t}^{D} \times \operatorname{Sav}_{j t}$, $\hat{r}_{j t}^{D} \times$ CustOwn u $_{j t}$ Standard errors are clustered by state, and are in parenthesis. Significance levels: * $<0.1, * *<0.05, * * *<0.01$. The data are from the FDIC (SDI and SOD).

\begin{tabular}{|c|c|c|c|}
\hline \multirow[t]{2}{*}{ Dependent variable: } & \multirow[t]{2}{*}{$r_{j t}^{D}$} & \multicolumn{2}{|c|}{$\ln \left(s_{j t}\right)-\ln \left(s_{0 t}\right)$} \\
\hline & & OLS & IV \\
\hline Index $_{j t}$ & $\begin{array}{c}0.0001^{* *} \\
(0.0000)\end{array}$ & & \\
\hline$r_{j t}^{D}$ & & $\begin{array}{l}-0.07 \\
(0.24)\end{array}$ & $\begin{array}{c}137.59^{* *} \\
(54.49)\end{array}$ \\
\hline$r_{j t}^{D} \times S a v_{j t}$ & & $\begin{array}{c}0.84^{* *} \\
(0.41)\end{array}$ & $\begin{array}{c}-14.59^{* * *} \\
(5.53)\end{array}$ \\
\hline$r_{j t}^{D} \times C u s t O w n_{j t}$ & & $\begin{array}{c}1.51^{* *} \\
(0.69)\end{array}$ & $\begin{array}{c}5.83^{* *} \\
(2.67)\end{array}$ \\
\hline $\operatorname{Sav}_{j t}$ & $\begin{array}{c}0.0071^{* * *} \\
(0.0001)\end{array}$ & $\begin{array}{c}0.11^{* * *} \\
(0.02)\end{array}$ & $\begin{array}{l}-0.28 \\
(0.19)\end{array}$ \\
\hline CustOwn $_{j t}$ & $\begin{array}{c}0.0002 \\
(0.0002)\end{array}$ & $\begin{array}{c}0.01 \\
(0.03)\end{array}$ & $\begin{array}{l}-0.16 \\
(0.11)\end{array}$ \\
\hline Empl per branch $_{j t}$ & $\begin{array}{c}-0.0011^{* * *} \\
(0.0001)\end{array}$ & $\begin{array}{c}0.76^{* * *} \\
(0.00)\end{array}$ & $\begin{array}{c}0.90 * * * \\
(0.06)\end{array}$ \\
\hline Number of branches $s_{j t}$ & $\begin{array}{c}-0.0009^{* * *} \\
(0.0001)\end{array}$ & $\begin{array}{c}0.10^{* * *} \\
(0.00)\end{array}$ & $\begin{array}{c}0.23^{* * *} \\
(0.05)\end{array}$ \\
\hline Branch density dit & $\begin{array}{c}0.0001 \\
(0.0001)\end{array}$ & $\begin{array}{c}0.77^{* * *} \\
(0.00)\end{array}$ & $\begin{array}{c}0.76^{* * *} \\
(0.02)\end{array}$ \\
\hline Out of state bank $k_{j t}$ & $\begin{array}{c}0.0013^{* * *} \\
(0.0002)\end{array}$ & $\begin{array}{c}-0.03^{* *} \\
(0.01)\end{array}$ & $\begin{array}{c}-0.22^{* * *} \\
(0.08)\end{array}$ \\
\hline Year FE & Yes & Yes & Yes \\
\hline State FE & Yes & Yes & Yes \\
\hline Observations & 50,332 & 50,332 & 50,332 \\
\hline
\end{tabular}




\section{Table 4: Results for Full Random Coefficients Logit Model}

This Table presents the results of the full random coefficient logit model. The instruments used for $r_{j t}^{D}$, $r_{j t}^{D} \times S_{a v}, r_{j t}^{D} \times C u s t O w n_{j t}$ are Index $x_{j t}, \hat{r}_{j t}^{D} \times S_{a v}{ }_{j t}, \hat{r}_{j t}^{D} \times C u s t O w n_{j t}$, with $\hat{r}_{j t}^{D}$ being the fitted value from the preliminary regression in Table 3 . Standard errors are in parenthesis. Significance levels: * $<0.1, * *<0.05, * * *<0.01$. The data are from the FDIC (SDI and SOD).

\begin{tabular}{|c|c|c|}
\hline & $\begin{array}{c}\text { Mean tastes } \\
(\hat{\theta})\end{array}$ & $\begin{array}{c}\text { Random component } \\
(\hat{\Sigma})\end{array}$ \\
\hline$r_{j t}^{D}$ & $\begin{array}{c}203.65^{* * *} \\
(0.07)\end{array}$ & $\begin{array}{c}2.31^{* * *} \\
(0.01)\end{array}$ \\
\hline$r_{j t}^{D} \times S a v_{j t}$ & $\begin{array}{c}-21.37^{* * *} \\
(0.14)\end{array}$ & $\begin{array}{c}0.29^{* * *} \\
(0.03)\end{array}$ \\
\hline$r_{j t}^{D} \times C u s t O w n_{j t}$ & $\begin{array}{c}8.31^{* * *} \\
(0.15)\end{array}$ & $\begin{array}{c}5.54^{* * *} \\
(0.03)\end{array}$ \\
\hline$S a v_{j t}$ & $\begin{array}{c}-0.43^{* * *} \\
(0.13)\end{array}$ & $\begin{array}{c}0.03 \\
(0.37)\end{array}$ \\
\hline CustOwn $n_{j t}$ & $\begin{array}{c}-0.35^{* * *} \\
(0.09)\end{array}$ & $\begin{array}{c}0.03 \\
(0.06)\end{array}$ \\
\hline Empl per branch $_{j t}$ & $\begin{array}{c}0.78^{* * *} \\
(0.20)\end{array}$ & $\begin{array}{c}0.35 \\
(0.58)\end{array}$ \\
\hline Number of branches ${ }_{j t}$ & $\begin{array}{c}0.89^{* * *} \\
(0.04)\end{array}$ & $\begin{array}{c}0.05 \\
(0.12)\end{array}$ \\
\hline Branch density $_{j t}$ & $\begin{array}{l}-0.08 \\
(0.07)\end{array}$ & $\begin{array}{c}0.48^{* * *} \\
(0.08)\end{array}$ \\
\hline Out of state bank $k_{j t}$ & $\begin{array}{l}-0.08 \\
(0.14)\end{array}$ & $\begin{array}{c}0.35 \\
(0.56)\end{array}$ \\
\hline Year FE & Yes & Yes \\
\hline State FE & Yes & Yes \\
\hline Observations & 50,332 & 50,332 \\
\hline \multicolumn{3}{|c|}{$\begin{array}{l}\text { Number of sets of starting values: } 50 \text {. Convergence achieved in } 49 \text { cases. } \\
\text { Convergence tolerance: } 10^{-16} \text {. }\end{array}$} \\
\hline
\end{tabular}




\section{Table 5: Deposit rate elasticities}

This Table presents the distribution of own and cross deposit rate elasticities, obtained using parameters' estimates of Table 4. The Table reports the 10th, 25th, 75th, and 90th percentiles, as well as median and mean. Cross deposit rate elasticities reflect changes in the quantity of the first listed bank type following a deposit rate change in the second listed bank type. For example, "Comm. - Inv.-own. sav." represents the quantity response of a commercial bank if an investor-owned savings bank increases its deposit rate.

\begin{tabular}{|c|c|c|c|c|c|c|}
\hline & \multicolumn{6}{|c|}{ Own deposit rate elasticities } \\
\hline & $10 \%$ & $25 \%$ & Median & Mean & $75 \%$ & $90 \%$ \\
\hline Commercial banks & 0.0133 & 0.8180 & 2.6727 & 9.0852 & 5.8329 & 11.1520 \\
\hline Inv.-own. savings banks & 0.0176 & 0.9406 & 2.8649 & 7.0300 & 6.1525 & 12.8120 \\
\hline Cust.-own. savings banks & 0.0043 & 1.0563 & 2.9888 & 5.2507 & 6.0915 & 9.7319 \\
\hline \multirow[t]{3}{*}{ All banks } & 0.0137 & 0.8437 & 2.7100 & 8.6417 & 5.8762 & 11.2050 \\
\hline & \multicolumn{6}{|c|}{ Cross deposit rate elasticities } \\
\hline & $10 \%$ & $25 \%$ & Median & Mean & $75 \%$ & $90 \%$ \\
\hline Comm. - Comm. & -0.0148 & -0.0046 & -0.0011 & -0.0207 & -0.0000 & -0.0000 \\
\hline Comm. - Inv.-own. sav. & -0.0288 & -0.0072 & -0.0014 & -0.0277 & -0.0000 & -0.0000 \\
\hline Comm. - Cust.-own. sav. & -0.0129 & -0.0040 & -0.0006 & -0.0104 & -0.0000 & -0.0000 \\
\hline Inv.-own. sav. - Comm. & -0.0161 & -0.0043 & -0.0009 & -0.0228 & -0.0000 & -0.0000 \\
\hline Inv.-own. sav. - Inv.-own. sav. & -0.0381 & -0.0103 & -0.0023 & -0.0327 & -0.0001 & -0.0000 \\
\hline Inv.-own. sav. - Cust.-own. sav. & -0.0154 & -0.0059 & -0.0018 & -0.0097 & -0.0001 & -0.0000 \\
\hline Cust.-own. sav. - Comm. & -0.0143 & -0.0039 & -0.0005 & -0.0166 & -0.0000 & -0.0000 \\
\hline Cust.-own. sav. - Inv.-own. sav. & -0.0267 & -0.0093 & -0.0023 & -0.0158 & -0.0001 & -0.0000 \\
\hline Cust.-own. sav. - Cust.-own. sav. & -0.0164 & -0.0067 & -0.0023 & -0.0110 & -0.0002 & -0.0000 \\
\hline All banks & -0.0158 & -0.0047 & -0.0011 & -0.0208 & -0.0000 & -0.0000 \\
\hline
\end{tabular}




\section{Table 6: Annual per-depositor welfare change percentiles}

This Table presents the annual per-depositor welfare change by percentiles. We compute the expected compensating variations for every market $t$, and multiply by the average deposit quantity in 2005 dollars in each market $t$. We then compute the 10th, 25th, 75th, and 90th percentiles, as well as median and mean, across markets. We also present these statistics focusing on particular years (1994 and 2005), and differentiating by presence of customer-owned savings banks. "States with low presence of cust.-own." are those belonging to the first quartile for total deposits managed by customer-owned savings banks. "States with high presence of cust.-own." are those belonging to the fourth quartile.

\begin{tabular}{|c|c|c|c|c|c|c|c|c|}
\hline & & $\mathrm{N}^{\circ}$ Obs. & $10 \%$ & $25 \%$ & Median & Mean & $75 \%$ & $90 \%$ \\
\hline \multirow[t]{2}{*}{ All sample } & $r_{j t}^{D}$ do not change & 564 & 0.00 & 0.00 & 0.08 & 0.36 & 0.44 & 1.09 \\
\hline & $r_{j t}^{D}$ change & 564 & -0.56 & -0.11 & 0.00 & 1.14 & 0.94 & 3.82 \\
\hline \multirow[t]{2}{*}{ Year: 1994} & $r_{j t}^{D}$ do not change & 47 & -0.10 & 0.00 & 0.09 & 0.25 & 0.31 & 1.17 \\
\hline & $r_{j t}^{D}$ change & 47 & -0.78 & -0.10 & 0.14 & 0.93 & 1.09 & 4.39 \\
\hline \multirow[t]{2}{*}{ Year: 2005} & $r_{j t}^{D}$ do not change & 47 & 0.00 & 0.00 & 0.14 & 0.52 & 0.67 & 1.18 \\
\hline & $r_{j t}^{D}$ change & 47 & -0.24 & 0.00 & 0.00 & 1.66 & 1.74 & 6.14 \\
\hline \multirow{2}{*}{$\begin{array}{l}\text { States with low } \\
\text { presence of cust.-own. }\end{array}$} & $r_{j t}^{D}$ do not change & 149 & 0.00 & 0.00 & 0.00 & 0.01 & 0.00 & 0.02 \\
\hline & $r_{j t}^{D}$ change & 149 & -0.01 & 0.00 & 0.00 & 0.17 & 0.00 & 0.00 \\
\hline \multirow{2}{*}{$\begin{array}{l}\text { States with high } \\
\text { presence of cust.-own. }\end{array}$} & $r_{j t}^{D}$ do not change & 132 & -0.30 & 0.14 & 0.70 & 0.96 & 1.36 & 2.73 \\
\hline & $r_{j t}^{D}$ change & 132 & -2.06 & -0.38 & 0.62 & 2.09 & 3.24 & 6.33 \\
\hline
\end{tabular}




\section{Table 7: Annual total welfare change percentiles}

This Table presents the annual total welfare changes by percentiles. We compute the expected compensating variations for every market $t$ and multiply it by the average deposit quantity in 2005 dollars and the total number of bank account choices in each market $t$. We then compute the 10th, 25th, 75th, and 90th percentiles, as well as median and mean, across markets. We also present these statistics focusing on particular years (1994 and 2005), and differentiating by presence of customer-owned savings banks. "States with low presence of cust.-own." are those belonging to the first quartile for total deposits managed by customer-owned savings banks. "States with high presence of cust.-own." are those belonging to the fourth quartile. Statistics are in millions of dollars.

\begin{tabular}{|c|c|c|c|c|c|c|c|c|}
\hline & & $\mathrm{N}^{\circ}$ Obs. & $10 \%$ & $25 \%$ & Median & Mean & $75 \%$ & $90 \%$ \\
\hline \multirow[t]{2}{*}{ All sample } & $r_{j t}^{D}$ do not change & 564 & 0.00 & 0.00 & 1.02 & 6.09 & 5.99 & 19.00 \\
\hline & $r_{j t}^{D}$ change & 564 & -8.08 & -1.17 & 0.00 & 22.02 & 11.11 & 64.58 \\
\hline \multirow[t]{2}{*}{ Year: 1994} & $r_{j t}^{D}$ do not change & 47 & -0.78 & 0.00 & 1.11 & 5.57 & 4.65 & 16.87 \\
\hline & $r_{j t}^{D}$ change & 47 & -6.92 & -1.17 & 0.59 & 28.80 & 18.93 & 118.27 \\
\hline \multirow[t]{2}{*}{ Year: 2005} & $r_{j t}^{D}$ do not change & 47 & 0.00 & 0.00 & 1.68 & 8.41 & 10.82 & 28.39 \\
\hline & $r_{j t}^{D}$ change & 47 & -3.53 & 0.00 & 0.00 & 23.32 & 23.66 & 108.19 \\
\hline \multirow{2}{*}{$\begin{array}{l}\text { States with low } \\
\text { presence of cust.-own. }\end{array}$} & $r_{j t}^{D}$ do not change & 149 & 0.00 & 0.00 & 0.00 & 0.55 & 0.00 & 0.54 \\
\hline & $r_{j t}^{D}$ change & 149 & -0.17 & 0.00 & 0.00 & 8.80 & 0.00 & 0.00 \\
\hline \multirow{2}{*}{$\begin{array}{l}\text { States with high } \\
\text { presence of cust.-own. }\end{array}$} & $r_{j t}^{D}$ do not change & 132 & -2.48 & 0.40 & 4.83 & 12.28 & 17.62 & 33.94 \\
\hline & $r_{j t}^{D}$ change & 132 & -12.24 & -2.25 & 5.95 & 25.73 & 40.86 & 82.93 \\
\hline
\end{tabular}




\section{Appendix}

\section{Model of Banking under Investor and Customer Ownership}

\section{Setup}

We consider an economy in which there are $J$ perfectly differentiated banks competing, $j=1, \ldots, J$. They are pure intermediaries with no equity, simply lending all deposits that they receive.

The total supply of deposits $q^{D}\left(r^{D}\right)$ is a function of the $J$-vector of each bank's deposit rate $r_{j}^{D}$, and includes the supply of deposits $q_{j}^{D}\left(r^{D}\right)$ to bank $j$. Thus each bank's deposit supply depends on the vector of deposit rates offered by all banks in the market. Likewise, total loan demand $q^{L}\left(r^{L}\right)$ is a function of the $J$-vector of each bank's loan rates $r_{j}^{L}$, and bank $j$ faces loan demand $q_{j}^{L}\left(r^{L}\right)$.

We assume that each bank's deposit supply is increasing in its own deposit rate, i.e. that $\frac{\partial q_{j}^{D}\left(r^{D}\right)}{\partial r_{j}^{D}}>0$. Equivalently, each bank's inverse deposit supply is increasing in its deposit quantity, i.e. $\frac{\partial r_{j}^{D}\left(q^{D}\right)}{\partial q_{j}^{D}}>0$. We also posit that each bank's loan demand is decreasing in its own loan rate, i.e. $\frac{\partial q_{j}^{L}\left(r^{L}\right)}{\partial r_{j}^{L}}<0$, so its inverse loan demand is decreasing in its loan quantity, i.e. $\frac{\partial r_{j}^{L}\left(q^{L}\right)}{\partial q_{j}^{L}}<0$.

Each bank $j$ 's only choice variable is its deposit rate $r_{j}^{D}$. Notice that by choosing its deposit rate - given the deposit rate choices of its rivals - bank $j$ 's deposit quantity $q_{j}^{D}\left(r^{D}\right)$ is determined by the market supply function for deposits. Furthermore, given that all deposits are assumed to be used to make loans, bank $j$ 's supply of loans is also determined, being $q_{j}^{L}\left(r^{D}\right)=q_{j}^{D}\left(r^{D}\right)$. Also, with bank $j$ 's loan supply having been determined, its loan rate is in turn also determined by the market inverse demand function for loans, $r_{j}^{L}\left(r^{D}\right) \equiv r_{j}^{L}\left(q_{j}^{L}\left(r^{D}\right)\right)=r_{j}^{L}\left(q_{j}^{D}\left(r^{D}\right)\right)$.

Banks engage in Bertrand-Nash competition. This means that they each choose their deposit rate taking the deposit rates of their rivals as given. Precisely, we assume that bank $j$ chooses its deposit rate on the assumption that $\frac{\partial r_{i}^{D}}{\partial r_{j}^{D}}=0$ for all $i \neq j$. We also assume the existence of a unique Bertrand-Nash equilibrium in pure strategies with positive deposit rates. 


\section{Objective Functions}

Banks can be either investor-owned $(I O)$ or customer-owned $(C O)$. Investor-owned banks maximize only their profits, while customer-owned maximize their profits jointly with customer surplus. ${ }^{19}$ In the case of customer-owned banks we assume that only the owners are customers of the relevant bank. This assumption can be relaxed by re-weighting the customer owners' objective function, but we do not do so here to highlight key differences between each bank type.

Investor-Owned Banks Investor-owned banks maximize profits, which comprise loan revenue net of deposit costs and fixed costs:

$$
\pi_{j}=r_{j}^{L}\left(q^{L}\right) q_{j}^{L}-r_{j}^{D} q_{j}^{D}\left(r^{D}\right)-F_{j}
$$

Fixed costs $F_{j}$ include all non-deposit related costs such as costs of labor, buildings, information technology, etc.. For simplicity we assume these fixed costs are nil. Given that each bank's choice of deposit rate determines its loan quantity and loan rate, we can write bank $j^{\prime}$ s profit as:

$$
\pi_{j}\left(r_{j}^{D}\right)=r_{j}^{L}\left(q_{j}^{D}\left(r^{D}\right)\right) q_{j}^{D}\left(r^{D}\right)-r_{j}^{D} q_{j}^{D}\left(r^{D}\right)
$$

Customer-Owned Banks Customer-owned banks value profits, but also the net customer surplus from deposit supply $\left(S_{j}^{D}\left(r_{j}^{D}\right)\right)$, and the net customer surplus from loan demand $\left(S_{j}^{L}\left(r_{j}^{D}\right)\right)$. Those net surpluses are respectively:

$$
\begin{gathered}
S_{j}^{D}\left(r_{j}^{D}\right)=\int_{0}^{r_{j}^{D}} q_{j}^{D}(x) d x \\
S_{j}^{L}\left(r_{j}^{D}\right)=\int_{0}^{q_{j}^{D}\left(r^{D}\right)} r_{j}^{L}(x) d x-r^{L}\left(q_{j}^{D}\left(r^{D}\right)\right) q_{j}^{D}\left(r^{D}\right)
\end{gathered}
$$

These surpluses are the shaded areas in Figure 5, in which we take linear deposit

\footnotetext{
${ }^{19}$ We abstract from incentive issues within banks under each ownership type. For a non-banking model comparing customer and investor ownership in a situation of managerial moral hazard with multitasking, see Meade (2014).
} 
supply and loan demand functions simply for illustrative purposes. Note that customer owners are assumed to care about profits as well as surpluses, even in situations where they are precluded by their bank's charter from participating in distributions of earnings or retained earnings. This is because they must at least respect the bank's break-even constraint (i.e. cannot simply maximize surpluses if doing so results in losses).

Figure 5: Bank j's depositor and borrower surpluses

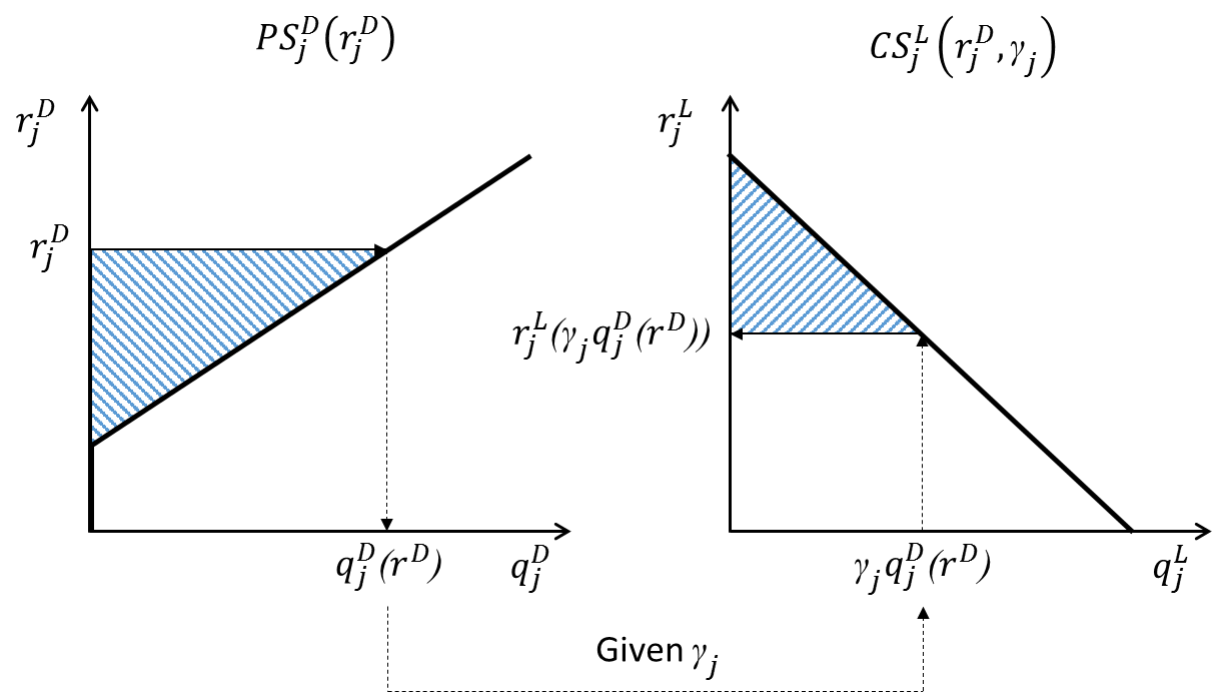

\section{Solution}

We solve our model with Bertrand-Nash equilibrium the relevant equilibrium concept. Thus each bank chooses its optimal deposit rate given the deposit rate choices of its rivals.

By direct differentiation of (8), bank $j$ 's first-order condition with respect $r_{j}^{D}$ under investor ownership is:

$$
\frac{\partial q_{j}^{D}}{\partial r_{j}^{D}}\left(\frac{\partial r_{j}^{L}}{\partial q_{j}^{L}} q_{j}^{D}+\left[r_{j}^{L}-r_{j}^{D}\right]\right)-q_{j}^{D}=0
$$

Turning to customer ownership, by direct differentiation of (9), we find that the sum of 
bank $j$ 's net depositor and borrower surpluses is increasing in $r_{j}^{D}$ :

$$
\frac{\partial}{\partial r_{j}^{D}}\left(S_{j}^{D}\left(r_{j}^{D}\right)+S_{j}^{L}\left(r_{j}^{D}\right)\right)=-\frac{\partial r_{j}^{L}}{\partial q_{j}^{L}} q_{j}^{D} \frac{\partial q_{j}^{D}}{\partial r_{j}^{D}}+q_{j}^{D}>0
$$

This is because $\frac{\partial r_{j}^{L}\left(q^{L}\right)}{\partial q_{j}^{L}}>0$ and $\frac{\partial q_{j}^{D}\left(r^{D}\right)}{\partial r_{j}^{D}}>0$ by assumption, and the remaining terms in the expression are positive by construction. The fact that total net surpluses are increasing in $r_{j}^{D}$ can be understood by reference to Figure 5. Given an upward-sloping deposit supply function, an increase in $r_{j}^{D}$ will cause $q_{j}^{D}$ to also increase, thus expanding the shaded area representing depositor surplus. In turn, an increase in $q_{j}^{D}$ leads to a corresponding increase in loan quantity $q_{j}^{L}$. Since loan demand is downward sloping, this causes a fall in $r_{j}^{L}$, thus expanding the shaded area representing borrower surplus. Hence an increase in $r_{j}^{D}$ simultaneously increases both net surpluses. Then, to obtain bank $j$ 's first order condition with respect $r_{j}^{D}$ under customer ownership, we add (11) to the left-hand side of (10). This yields:

$$
\frac{\partial q_{j}^{D}}{\partial r_{j}^{D}}\left(r_{j}^{L}-r_{j}^{D}\right)=0
$$

Under customer ownership, since $\frac{\partial q_{j}^{D}}{\partial r_{j}^{D}}>0$, bank $j$ optimally chooses $r_{j}^{D}$ so that it breaks even, with its marginal revenue $r_{j}^{L}$ equaling its marginal cost $r_{j}^{D}$. Significantly, this is true even with the banks competing oligopolistically.

We now characterize the optimal deposit rates under investor- and customer- ownership. Assuming that each bank's profit function is concave with an interior maximum, and that the customer owner's objective function is likewise, the situation is as depicted in Figure 6. If bank $j$ is investor-owned, its profit-maximizing deposit rate choice is $r_{j}^{D, I O}$ as shown. By contrast, from (11) we know that the combined net depositor and borrower surpluses of bank $j$ 's customers are increasing in $r_{j}^{D}$, so customer-owned bank $j$ optimally chooses $r_{j}^{D, C O}>r_{j}^{D, I O}$. This is because customer owners optimally trade off profits against depositor and borrower surpluses, with the result that they choose a deposit rate that is not profit maximizing. Indeed, it results in the customer-owned bank 
simply breaking even.

To conclude, our stylized model of bank behavior under investor- and customerownership makes three predictions. Relative to investor-owned banks, customer-owned banks offer a higher deposit rate, charge a lower loan rate, and serve more customers. Indeed, by setting a higher deposit rate, they receive more deposits and issue more loans.

\section{Figure 6: Optimal Deposit Rate Choices under Investor and Customer Own- ership}

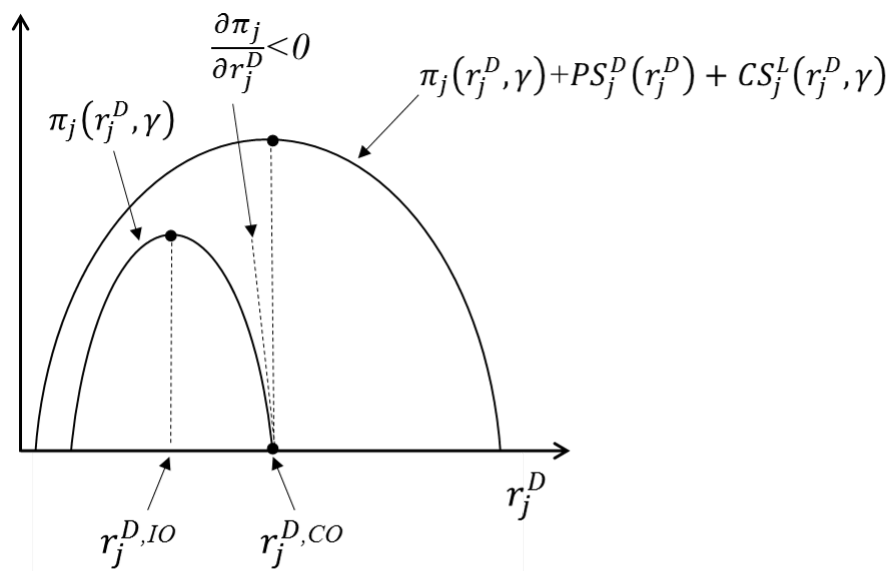

\section{Estimation Details}

Estimation of the full random coefficients deposit supply specification proceeds as follows. First, we sample $n s=100$ independent standard normal vectors for $\nu_{i}$ for each market. As in Train (2009), we use Halton sampling to improve efficiency. Next, we use logit estimates and random draws as initial estimates of, respectively, $\delta_{j t}$ and $\Sigma$. Given those initial values, we compute the predicted market shares using the empirical counterpart of (5). Given only $\Sigma$, we compute the value of $\delta_{j t}$ that minimizes the distance between observed and predicted market shares of each bank $j$ in market $t$, using the contraction mapping proposed by BLP. Based on this estimate of $\delta_{j t}$ for each market $t$, we then obtain an estimate of the unobserved bank characteristics term $\xi_{j t}$. This can be thought of as a structural error term suitable for GMM estimation purposes. However, $\xi_{j t}$ is expected to be correlated with the deposit rate. To resolve this endogeneity problem, we define 
$Z$ a set of suitable instruments. Given our current estimate of $\theta$ and $\Sigma$, we compute an updated estimate of $\theta$ and $\Sigma$ using the following GMM problem:

$$
(\hat{\theta}, \hat{\Sigma})=\arg \min _{\theta, \Sigma} \xi(\theta, \Sigma)^{\prime} Z \Phi^{-1} Z^{\prime} \xi(\theta, \Sigma)
$$

where $\Phi$ is a consistent estimate of $\mathbb{E}\left(Z^{\prime} \xi \xi^{\prime} Z\right)$.

The above steps are repeated until the resulting objective function value, or estimate of $\theta$ and $\Sigma$, converges to within a pre-specified tolerance level. Additionally, the entire algorithm is repeated for multiple sets of starting values for $\Sigma$. Indeed, since $\Sigma$ enters the vector $\xi(\theta, \Sigma)$ non-linearly, the above GMM estimate must be obtained using numerical procedures. It is well-documented that the choices of optimization method, convergence tolerance levels and sets of starting values, are all critical to obtaining reliable estimates (Knittel and Metaxoglou (2014)). We implemented the algorithm with convergence tolerances of $10^{-16}$, and 50 different sets of starting values for $\Sigma$.

As in Nevo (2001), the asymptotic covariance matrix for the parameter estimates is a variation on that implemented by BLP based on the then working paper version of Berry et al. (2004). Specifically, we use:

$$
\left(\Gamma^{\prime} W \Gamma\right)^{-1} \Gamma^{\prime} W \Phi W \Gamma\left(\Gamma^{\prime} W \Gamma\right)^{-1}
$$

where $\Phi$ is as in (13), $W=\left(Z^{\prime} Z\right)^{-1}$, and $\Gamma$ is the limit of the derivative of the GMM moment condition $\xi(\theta)$ with respect to $\theta$ as the number of banks $J$ increases. As discussed in Berry et al. (2004), for consistent and asymptotic normal parameter estimates in random coefficients logit models, it is necessary for $n s$ to be large relative to $J$, which is why we opted for $n s=100$ and used Halton sampling to improve sampling efficiency.

Without random coefficients (i.e. if $\alpha_{i}=\alpha$ and $\beta_{i}=\beta$ for all $i$ ) our model reduces to a multinomial logit model. As shown by Berry (1994), the BLP contraction mapping to recover $\delta_{j t}$ is no longer required in that case, and $\delta_{j t}$ can instead be computed by a simple inversion. $\theta$ can be recovered using standard regression techniques, after appropriately instrumenting for deposit rates to allow for the endogeneity between deposit rate and unobserved bank characteristics $\xi_{j t}$ identified above. 